Article

\title{
Analysis of Differentially Expressed Genes in Coronary Artery Disease by Integrated Microarray Analysis
}

\author{
Meenashi Vanathi Balashanmugam ${ }^{1}$, Thippeswamy Boreddy Shivanandappa ${ }^{1}$, \\ Sivagurunathan Nagarethinam ${ }^{1}$, Basavaraj Vastrad ${ }^{2}$ and Chanabasayya Vastrad ${ }^{3, *}$ (D) \\ 1 Department of Biomedical Sciences, College of Pharmacy, Shaqra University, \\ Al Dawadmi 11911, Saudi Arabia; meenashivanathi@gmail.com (M.V.B.); t_swamy@hotmail.com (T.B.S.); \\ sivagurunathann@gmail.com (S.N.) \\ 2 Department of Pharmaceutics, SET'S College of Pharmacy, Dharwad, Karnataka 580002, India; \\ basavarajmv@gmail.com \\ 3 Biostatistics and Bioinformatics, Chanabasava Nilaya, Bharthinagar, Dharwad 580001, Karanataka \\ * Correspondence: channu.vastrad@gmail.com; Tel.: +91-9480-073398
}

Received: 16 November 2019; Accepted: 20 December 2019; Published: 25 December 2019

\begin{abstract}
Coronary artery disease (CAD) is a major cause of end-stage cardiac disease. Although profound efforts have been made to illuminate the pathogenesis, the molecular mechanisms of CAD remain to be analyzed. To identify the candidate genes in the advancement of CAD, microarray dataset GSE23766 was downloaded from the Gene Expression Omnibus database. The differentially expressed genes (DEGs) were identified, and pathway and gene ontology (GO) enrichment analyses were performed. The protein-protein interaction network was constructed and the module analysis was performed using the Biological General Repository for Interaction Datasets (BioGRID) and Cytoscape. Additionally, target genes-miRNA regulatory network and target genes-TF regulatory network were constructed and analyzed. There were 894 DEGs between male human CAD samples and female human CAD samples, including 456 up regulated genes and 438 down regulated genes. Pathway enrichment analyses revealed that DEGs (up and down regulated) were mostly enriched in the superpathway of steroid hormone biosynthesis, $A B C$ transporters, oxidative ethanol degradation III and Complement and coagulation cascades. Similarly, geneontology enrichment analyses revealed that DEGs (up and down regulated) were mostly enriched in the forebrain neuron differentiation, filopodium membrane, platelet degranulation and blood microparticle. In the PPI network and modules (up and down regulated), MYC, NPM1, TRPC7, UBC, FN1, HEMK1, IFT74 and VHL were hub genes. In the target genes-miRNA regulatory network and target genes-TF regulatory network (up and down regulated), TAOK1, KHSRP, HSD17B11 and PAH were target genes. In conclusion, the pathway and GO ontology enriched by DEGs may reveal the molecular mechanism of CAD. Its hub and target genes, MYC, NPM1, TRPC7, UBC, FN1, HEMK1, IFT74, VHL, TAOK1, KHSRP, HSD17B11 and PAH were expected to be new targets for CAD. Our finding provided clues for exploring molecular mechanism and developing new prognostics, diagnostic and therapeutic strategies for CAD.
\end{abstract}

Keywords: coronary artery disease; differentially expressed genes; hub genes; protein-protein interaction network; pathway enrichment analyses

\section{Introduction}

Coronary artery disease (CAD), the most common type of heart disease, is considered a complicated disease. CAD is caused due to narrowing or blockage of the coronary arteries due to buildup of 
cholesterol and fatty deposits on the inner walls of the arteries [1]. The causes of CAD consist of genetic risk and environmental influence [2-4]. Compared with histological classification, genes play many key roles in the diagnosis, treatment, and prognosis of CAD [5]. Alteration in genes such as ABCA1 [6] and human paraoxonase/arylesterase (HUMPONA) [7] were associated with development of CAD. Polymorphism in genes such as $\beta$ fibrinogen [8] apolipoprotein A-I [9] heme oxygenase-1 [10], PON1 and PON2 [11], PAI-1 [12], MMP-2, MMP-3, MMP-9 and MMP-12 [13], NADH/NADPH oxidase [14] and angiotensin II type 1 receptor [15] were responsible for the progression of CAD. To date, the precise molecular mechanisms of CAD are still unknown, it is extremely important to uncover the underlying genes contributed to CAD.

With the rapid development of microarray technology, some high throughput platforms for analysis of gene expression are widely used to explore the differentially expressed genes (DEGs) during progression of cardiac diseases and molecular mechanisms of cardiovascular drugs [16,17]. However, the DEGs diagnosed with microarray dependon the sample size, gender, grading, and ethnic group, etc. The genes obtained from microarrays might be more representative.

In the current study, messenger RNA (mRNA) microarray datasets (GSE23766) were downloaded from the Gene Expression Omnibus (GEO) database, which were subsequently analyzed to obtain overlapping DEGs. Pathway and gene ontology (GO) enrichment analysis and PPI network construction, module analysis, target genes-miRNA regulatory network construction and target genes-TF regulatory network construction were applied to diagnose the important genes linked with CAD.

\section{Materials and Methods}

\subsection{Microarray Data and Data Processing}

Flowchart of materials and methods is shown in Figure 1. The gene expression profile GSE23766 was downloaded from the GEO database (http://www.ncbi.nlm.nih.gov/geo/), which were all based on GPL6480 Agilent-014850 Whole Human Genome Microarray $4 \times 44$ K G4112F (AGILENT TECHNOLOGIES, INC, 5301 Stevens Creek Blvd, Santa Clara, CA 95051, USA). The GSE23766 dataset contained 16 male human CAD samples and 16 female human CAD samples. Series Matrix text files of the dataset were obtained. Subsequently, background correction, quartile normalization and probe summarization were performed with the limma R package $[18,19]$.

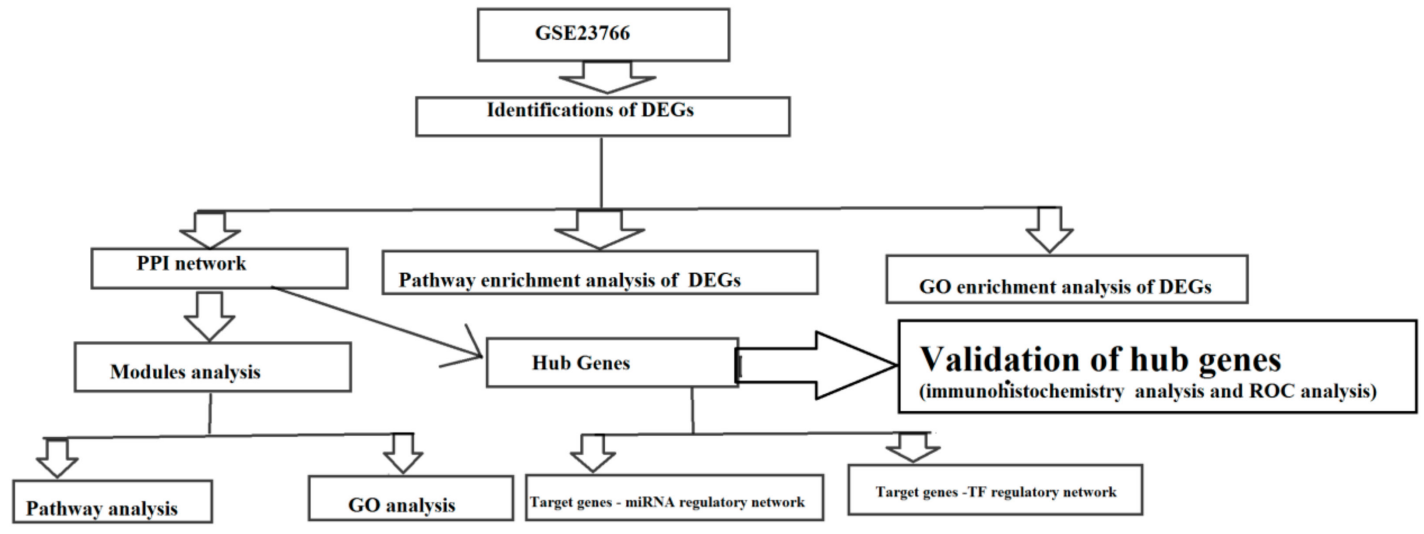

Figure 1. Study design (flow diagram of study).

\subsection{Identification of DEGs between Male $C A D$ and Female $C A D$ Samples}

In this study, we used an empirical Bayes t-test (eBayes) to identify the DEGs between male human CAD samples and female human CAD samples with cutoff value $\mid \log$ 2(Fold Change) $\mid>0.1694$ for up regulated genes, $\mid \log 2$ (Fold Change) $\mid>0.229$ for down regulated genes and adjusted $p$-value $<0.05$. 


\subsection{Pathway Enrichment Analysis of DEGs}

The pathway enrichment of candidate DEGs were analyzed using multiple online databases. ToppGene (ToppFun) (https://toppgene.cchmc.org/enrichment.jsp) [20] is a website for gene annotation and visualization with an integrated discovery function and can, therefore, provide the biological meaning of genes, including gene annotations and visualization. Pathway enrichment analysis of DEGs was carried out using the Kyoto Encyclopedia of Genes and Genomes (KEGG; http://www. genome.jp/kegg/) [21], Pathway Interaction Database (PID, http://pid.nci.nih.gov/) [22], Reactome (https://reactome.org/PathwayBrowser/) [23], Molecular signatures database (MSigDB, http://software. broadinstitute.org/gsea/msigdb/) [24], GenMAPP (http://www.genmapp.org/) [25], Pathway Ontology (https://bioportal.bioontology.org/ontologies/PW) [26] and PantherDB (http://www.pantherdb.org/) [27] websites, with $p<0.05$ as the cutoff value.

\subsection{GO Enrichment Analysis of DEGs}

GO (http://www.geneontology.org/) [28] analysis is a common genes analysis method, which can contribute functional classification for genomic data, with categories of biological processes (BP), cellular component (CC), and molecular function (MF). ToppGene (ToppFun) (https://toppgene.cchmc. org/enrichment.jsp) [20] is an online tool for gene functional classification, which can systematic and integrative analysis of large gene lists.

\subsection{Comprehensive Analysis of PPI Network and Modules}

We used Biological General Repository for Interaction Datasets (BioGRID) (https://thebiogrid.org/) to assess protein-protein interaction (PPI) information [29]. In addition, in order to explore the relationship between DEGs, we used the BioGRID which is integrated with various protein interaction database partners such as Molecular INTeraction Database (MINT, https://mint.bio. uniroma2.it/) [30], IntAct (https://www.ebi.ac.uk/intact/) [31], Database of Interacting Proteins (DIP, https://dip.doe-mbi.ucla.edu/dip/Main.cgi) [32], Pathway Commons (http://www.pathwaycommons. org/) [33], iRefIndex (http://irefindex.org/wiki/index.php?title=iRefIndex) [34], STRING (https://stringdb.org/) [35], MatrixDB (http://matrixdb.univ-lyon1.fr/) [36], MPIDB (https://www.jcvi.org/mpidb/ about.php) [37], InnateDB (https://www.innatedb.com/) [38], iRefWeb (http://wodaklab.org/iRefWeb/ search/index) [39], I2D (http://ophid.utoronto.ca/ophidv2.204/) [40] and converted the results visually by using Cytoscape software (http://www.cytoscape.org/) [41]. Topological properties of PPI network such as node degree [42], betweenness [43], stress [44], closeness [45] and clustering coefficient [46] were calculated. Furthermore, module analysis was performed by using the PEWCC1 [47] plugin (version 1.3) to explore the most important clustering modules in the huge PPI network (degree cutoff $=5, \mathrm{k}$-core $=2$, node score cutoff $=0.2$, and max. Depth rom Seed: 100).

\subsection{Construction of Target Genes-miRNA Regulatory Network}

The miRNAs of target genes were predicted by two established miRNA target prediction databases such as DIANA-TarBase (http://diana.imis.athena-innovation.gr/DianaTools/index.php? $\mathrm{r}=$ tarbase/index) [48] and miRTarBase (http://mirtarbase.mbc.nctu.edu.tw/php/download.php) [49]. The miRNAs predicted by online tool NetworkAnalyst (https://www.networkanalyst.ca/) [50] were selected as the miRNAs of target genes. A network based on correlation analysis of target genes and miRNAs linked with CAD was constructed by Cytoscape software (http://www.cytoscape.org/, version 3.7.2, National Institutes of Health, Bethesda, MD, USA) [41]. In the network, a green (up regulated) and red (down regulated) circular node represented the target genes and a white and blue diamond shape node represented the miRNA, their interaction was represented by a line. The numbers of lines in the networks indicated the contribution of one miRNA to the surrounding target genes, and the higher the degree, the more central the target gene was within the network. 


\subsection{Construction of Target Genes-TF Regulatory Network}

The transcription factors (TFs) of target genes were predicted by established TF target prediction databases such as JASPAR (http://jaspar.genereg.net/) [51]. The miRNAs predicted by online tool Network Analyst (https://www.networkanalyst.ca/) [50] were selected as the TFs of target genes. A network based on correlation analysis of target genes and TFs linked with CAD was constructed by Cytoscape software (http://www.cytoscape.org/) [41]. In the network, a green (up regulated) and red (down regulated) circular node represented the target genes and a gray and blue triangle shape node represented the TF, their interaction was represented by a line. The numbers of lines in the networks indicated the contribution of one TF to the surrounding target genes, and the higher the degree, the more central the target gene was within the network.

\subsection{Hub Gene Expression Levels in CAD}

The Human Protein Atlas (HPA) (https://www.proteinatlas.org/) was used to validate the expression level of the hub genes [52].

\subsection{Receiver Operating Characteristic Curve Analysis}

Receiver operating characteristic curve (ROC) analysis was performed using $\mathrm{R}$ package "pROC" [53] to distinguish male CAD samples from female CAD tissues. In GSE23766, we worked out the AUC to distinguish male CAD samples from female CAD tissues. After that, we compared the expression levels of candidate hub genes in male CAD and female CAD tissues using GSE23766.

\section{Results}

\subsection{Identification of DEGs}

After quality control, normalization and batch effect adjustment, gene expression profiles from CAD samples with male and female were compared. The boxplot proved good normalization of the GSE23766 data (Figure 2A,B). A total of 894 significant DEGs (adjusted $p$-value $<0.05, \mid \log 2$ (Fold Change) $\mid>0.1694$ for up regulated genes, $\mid \log 2$ (Fold Change) $\mid>0.229$ for down regulated genes), including 456 up regulated and 438 down regulated genes, were identified from GSE23766 dataset (Table S1). The volcano plot of each gene expression profile data was shown in Figure 3. Hierarchical clustering analysis showed the expression pattern of DEGs among samples, which suggested that the expression of genes in CAD with male significantly differ from those in adjacent CAD with female (Figures 4 and 5).
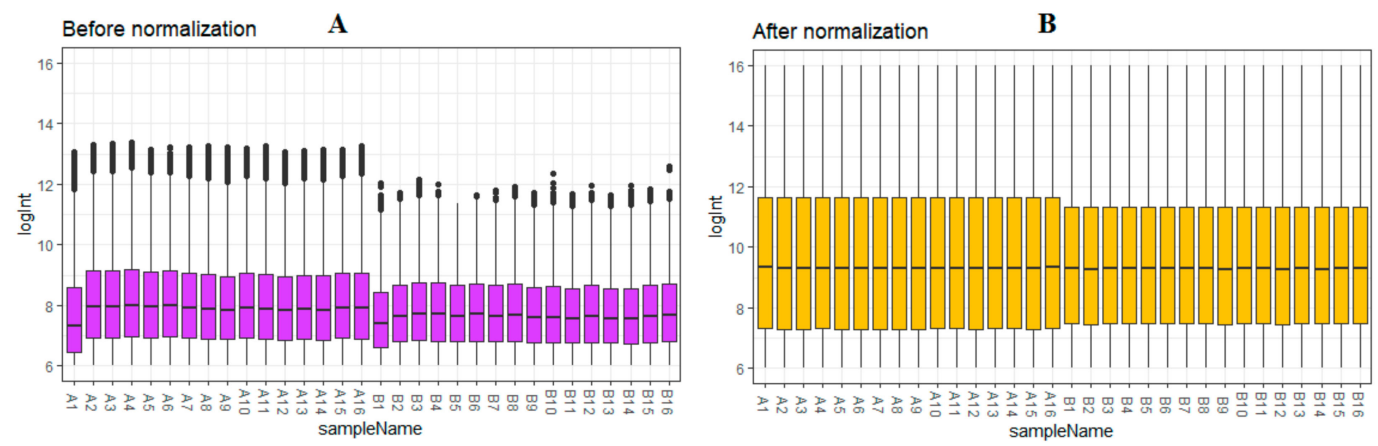

Figure 2. Box plots of the gene expression data before (A) and after normalization (B). Horizontal axis represents the sample symbol and the vertical axis represents the gene expression values. The black line in the box plot represents the median value of gene expression. (A1-A16 = male human CAD samples; B1-B16 = female human CAD samples). 


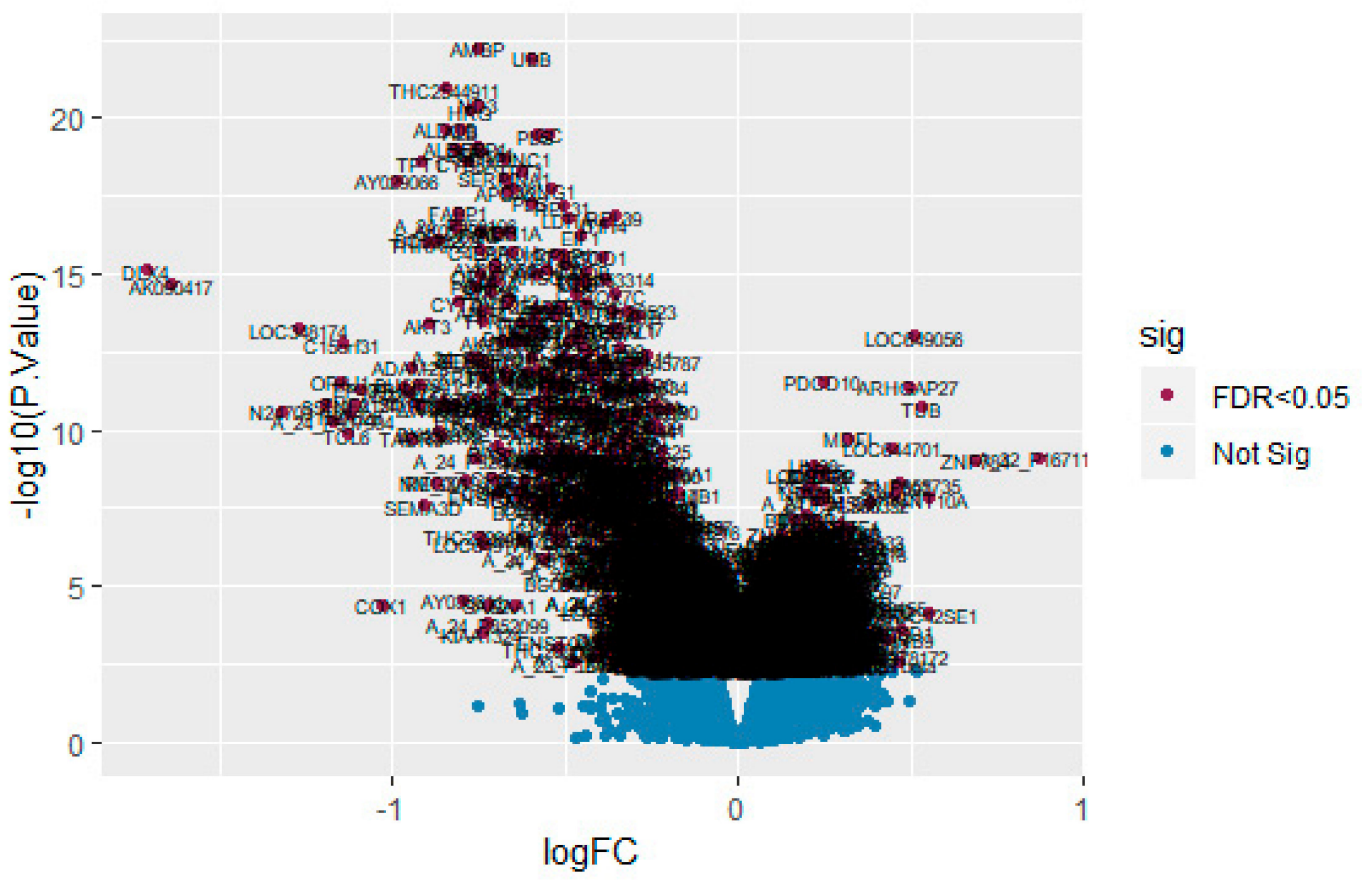

Figure 3. Volcano plot of differentially expressed genes. Genes with a significant change of more than two-fold were selected.
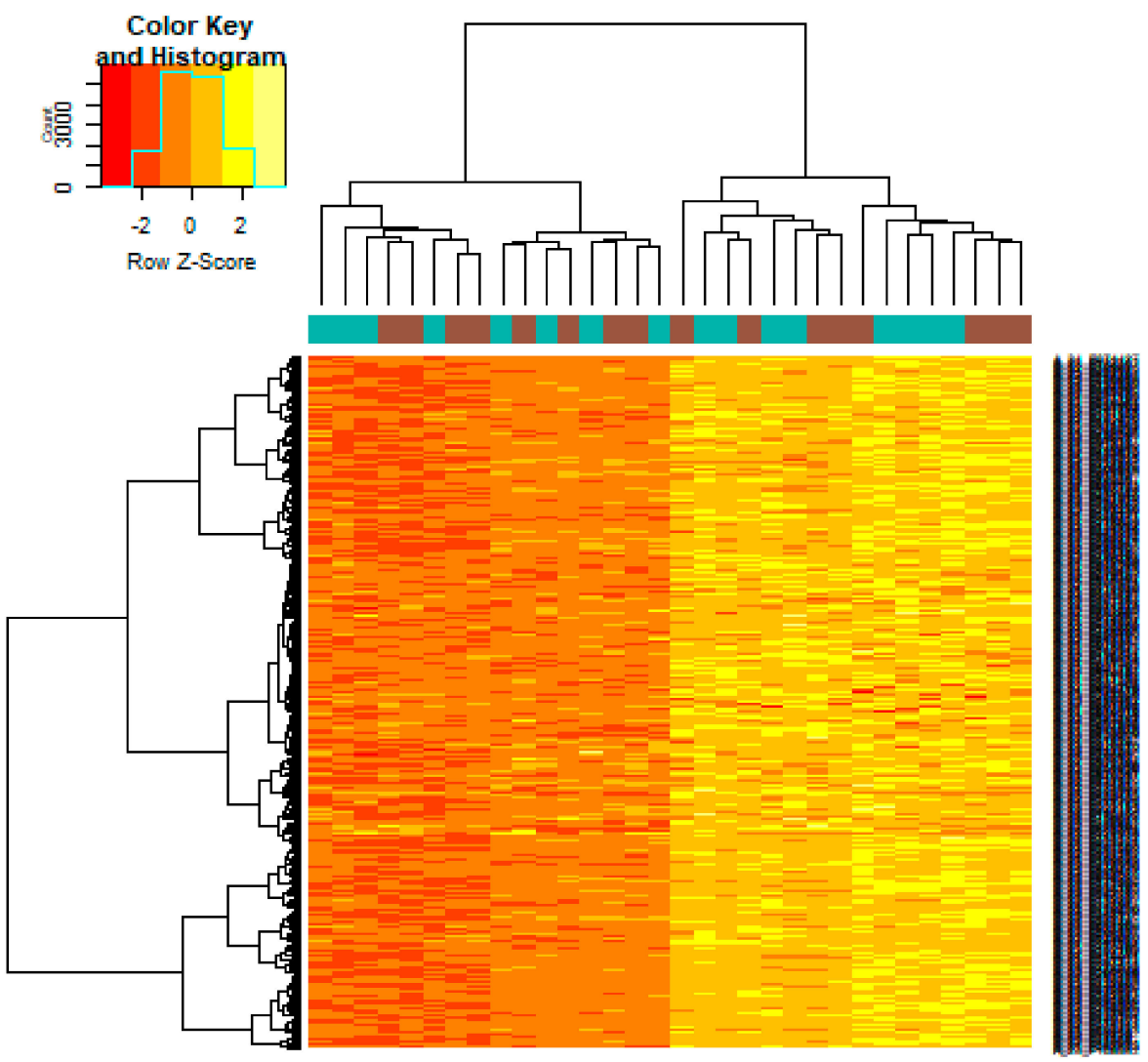

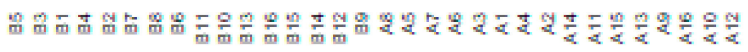

Figure 4. Heat map of up regulated differentially expressed genes. Legend on the top left indicate log fold change of genes. (A1, A2, A3, A4, A5, A6, A7, A8, A9, A10, A11, A12, A13, A14, A15, A16 = male human CAD samples; B1, B2, B3, B4, B5, B6, B7, B8, B9, B10, B11, B12, B13, B14, B15, B16 = female human CAD samples). 


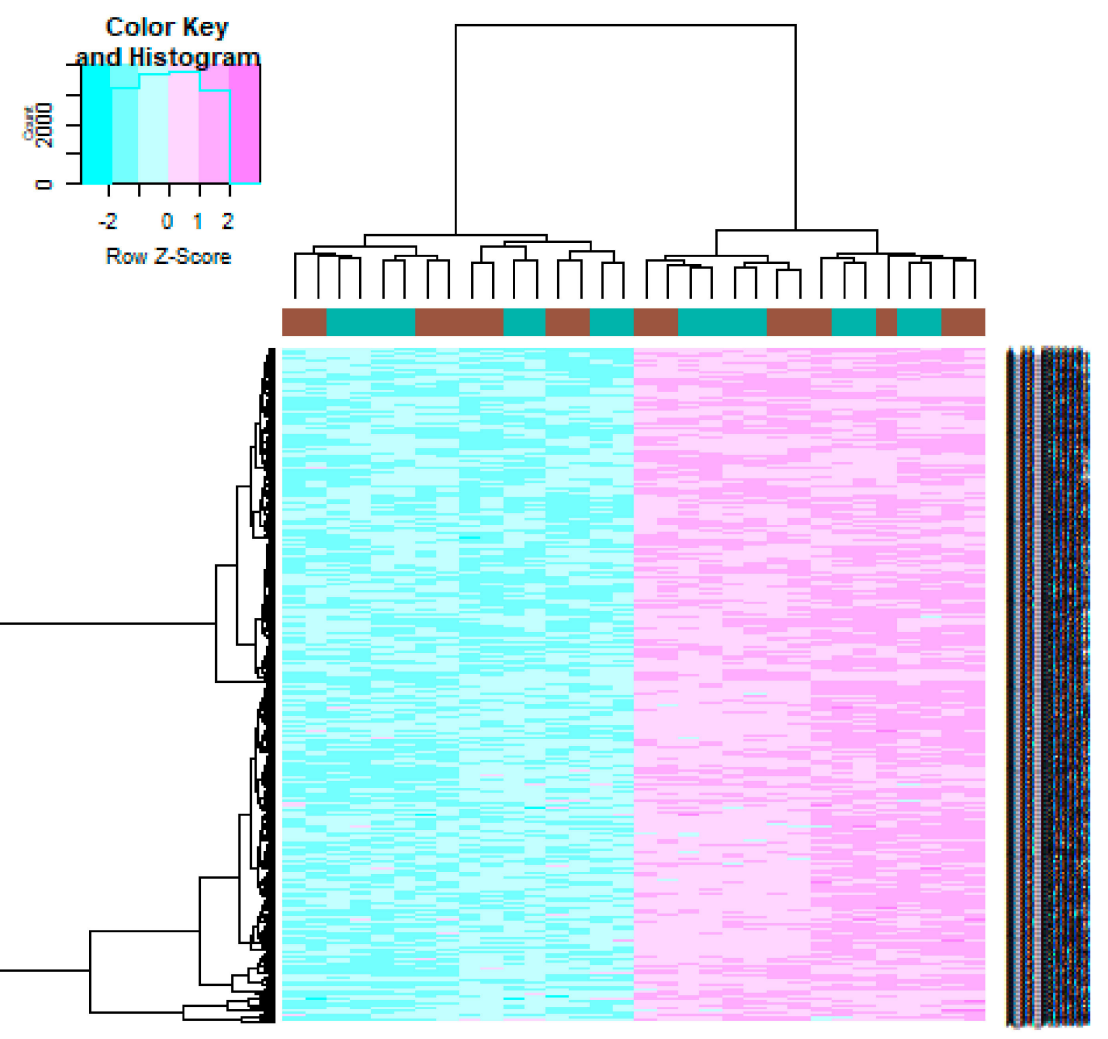

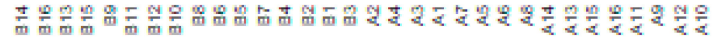

Figure 5. Heat map of down regulated differentially expressed genes. Legend on the top left indicate log fold change of genes. (A1, A2, A3, A4, A5, A6, A7, A8, A9, A10, A11, A12, A13, A14, A15, A16 = male human CAD samples; B1, B2, B3, B4, B5, B6, B7, B8, B9, B10, B11, B12, B13, B14, B15, B16 = female human CAD samples).

\subsection{Pathway Enrichment Analysis}

To gain further insight into the identified DEGs (up and down regulated genes), pathway and GO enrichment analyses were conducted using ToppGene and are given in Tables S2 and S3. Pathway enrichment analysis showed that up regulated genes were mainly involved in PABC transporters, BARD1 signaling events, androgen/estrogene/progesterone biosynthesis and multidrug resistance-associated protein mediated transport, while down regulated genes were mainly involved to complement and coagulation cascades, FOXA2 and FOXA3 transcription factor networks, fatty acid metabolism and fibrinolysis pathway. Gene ontology (GO) enrichment analysis showed that up regulated genes were mainly associated in biological processes (BP), cellular component (CC) and molecular function (MF), including forebrain neuron differentiation, filopodium membrane and DNA binding, bending, while down regulated genes were mainly associated in biological processes (BP), cellular component (CC) and molecular function (MF), including platelet degranulation, blood microparticle and peptidase regulator activity.

\subsection{GO Enrichment Analysis of DEGs}

Enrichment analyses for the up regulated and down regulated genes were performed by ToppGene. The up regulated genes were mainly enriched in forebrain neuron differentiation and negative regulation of immune system process by BP, filopodium membrane and nucleolus by CC and DNA binding, bending and protein dimerization activity by MF, respectively (Table S4). Meanwhile, down regulated genes were mainly enriched in platelet degranulation and response to inorganic substance by BP, blood microparticle and extracellular space by $\mathrm{CC}$ and peptidase regulator activity and endopeptidase inhibitor activity by MF, respectively (Table S5). 


\subsection{Comprehensive Analysis of PPI Network and Modules}

The PPI network of up regulated genes consisted of 5840 nodes and 16,142 edges (Figure 6). Hub genes with high node degree such as MYC (degree =998), NPM1 (degree = 820), UBE2D3 (degree = 488), TERF1 (degree $=429$ ) and PSMA3 (degree $=403$ ) were listed in Table S6. $R$ square $=0.724$ and correlation coefficient $=0.986$ for node degree (Figure 7A). Hub genes with high betweenness such as MYC (betweenness = 0.15430897), NPM1 (betweenness =0.11756148), TERF1 (betweenness $=0.06992938$ ), PSMA3 (betweenness $=0.05585022$ ) and MDFI (betweenness $=0.055025$ ) were listed in Table S6. $\mathrm{R}$ square $=0.473$ and correlation coefficient $=0.170$ for betweenness (Figure $7 \mathrm{~B})$. Hub genes with high stress such as MYC (stress = 168499346), NPM1 (stress = 107362468), PSMA3 (stress = 49381886), MDFI (stress = 39487556) and TERF1 (stress = 32105062) were listed in Table S6. R square $=0.017$ and correlation coefficient $=-0.032$ for stress (Figure $7 \mathrm{C}$ ). Hub genes with high closeness such as NPM1 (closeness $=0.38413706)$, MYC (closeness = 0.37588193), TERF1 (closeness =0.36795083), CCT6A (closeness $=0.36512827$ ) and RPS14 (closeness $=0.36450945)$ were listed in Table S6. $\mathrm{R}$ square $=0.286$ and correlation coefficient $=0.183$ for closeness (Figure 7D). Hub genes with low clustering coefficient such as TRPC7 (clustering coefficient $=0$ ), TNFRSF11B (clustering coefficient $=0$ ), ABCB4 (clustering coefficient =0), DPY19L2 (clustering coefficient $=0$ ) and ABCG5 (clustering coefficient $=0$ ) were listed in Table S6. R square $=0.471$ and correlation coefficient $=0.790$ for clustering coefficient (Figure 7E). The PPI network of down regulated genes consisted of 4014 nodes and 8815 edges (Figure 8). Hub genes with high node degree such as UBC (degree = 799), FN1 (degree =718), VHL (degree = 587), HSPA8 (degree $=576$ ) and SOD1 (degree $=245$ ) were listed in Table S6. R square $=0.710$ and correlation coefficient $=0.974$ for node degree (Figure 9A). Hub genes with high betweenness such as FN1 (betweenness $=0.32861508)$, UBC (betweenness $=0.21817265)$, HSPA8 (betweenness $=0.17366877$ ), VHL (betweenness $=0.09640801$ ) and SOD1 (betweenness $=0.0712639$ ) were listed in Table S6. $\mathrm{R}$ square $=0.394$ and correlation coefficient $=0.172$ for betweenness (Figure 9B). Hub genes with high stress such as UBC (stress = 75534956), FN1 (stress = 48390654), HSPA8 (stress = 48349874), VHL (stress $=18147816$ ) and SOD1 (stress $=17465716)$ were listed in Table S6. R square $=0.282$ and correlation coefficient $=0.015$ for stress (Figure $9 \mathrm{C}$ ). Hub genes with high closeness such as FN1 (closeness $=0.437081)$, HSPA8 (closeness $=0.39532803)$, UBC (closeness $=0.39232515)$, VHL (closeness $=0.37550751)$ and SOD1 (closeness $=0.36971275)$ were listed in Table S6. $\mathrm{R}$ square $=0.106$ and correlation coefficient $=0.224$ for closeness (Figure 9D). Hub genes with low clustering coefficient such as HEMK1 (clustering coefficient = 0), ADH1C (clustering coefficient = 0), CYSLTR2 (clustering coefficient $=0$ ), CYP2E1 (clustering coefficient $=0$ ) and COX7C (clustering coefficient $=0$ ) were listed in Table S6. $R$ square $=0.651$ and correlation coefficient $=0.940$ for clustering coefficient (Figure 9E).

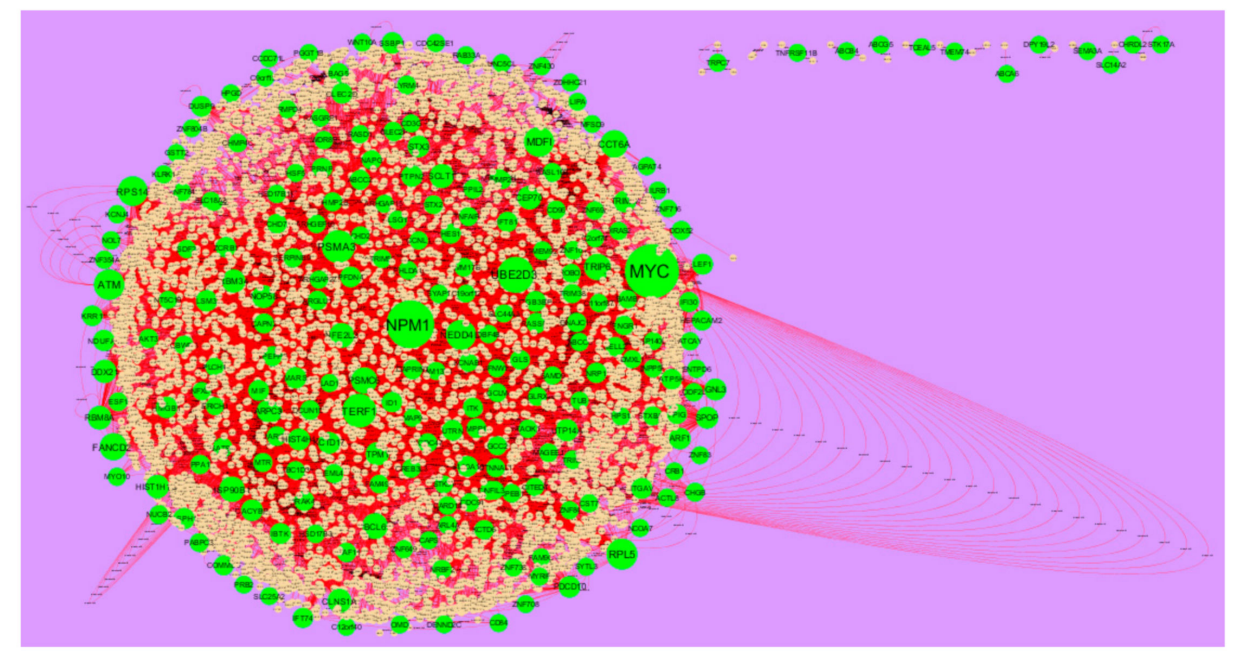

Figure 6. Protein-protein interaction network of up regulated genes. Green nodes denotes up regulated genes. 
$\mathbf{A}$

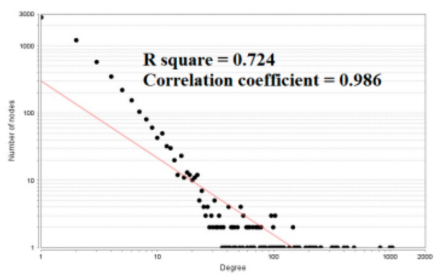

D

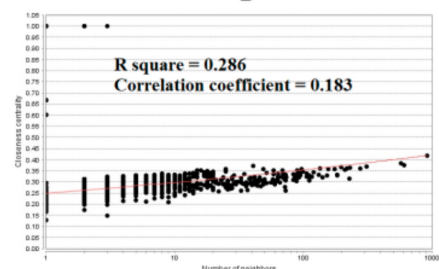

B
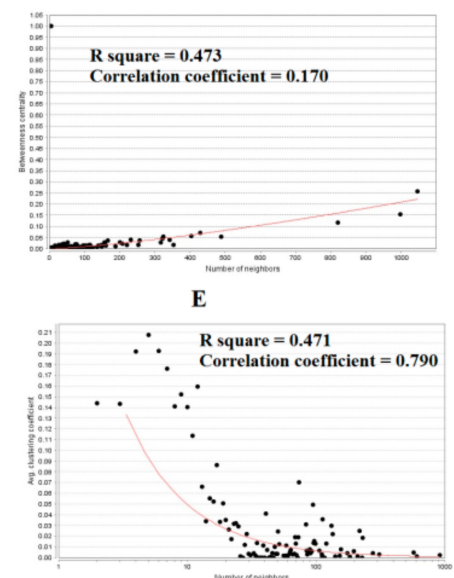

C

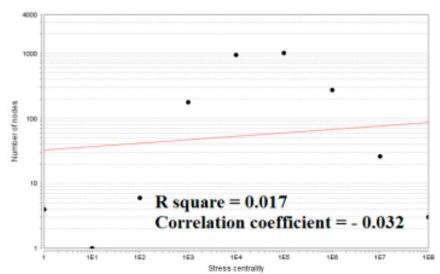

Figure 7. Regression diagrams for up regulated genes (A) Node degree; (B) Betweenness centrality; (C) Stress centrality; (D) Closeness centrality; (E) Clustering coefficient.

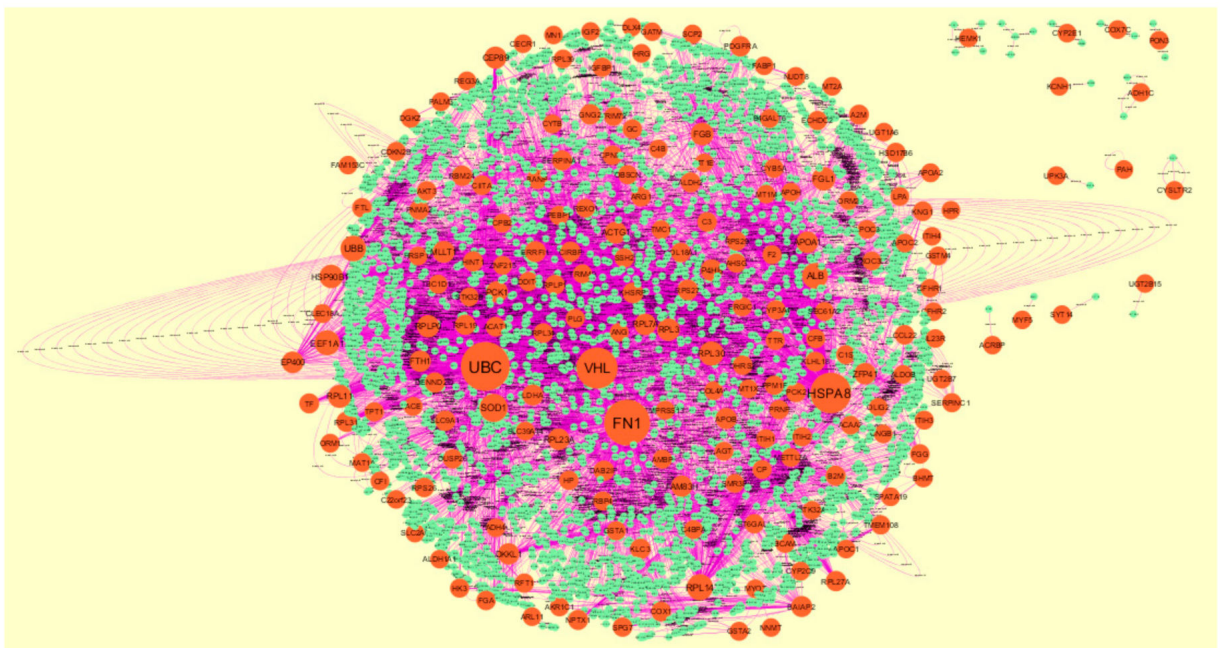

Figure 8. Protein-protein interaction network of down regulated genes. Orange nodes denotes down regulated genes.

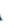
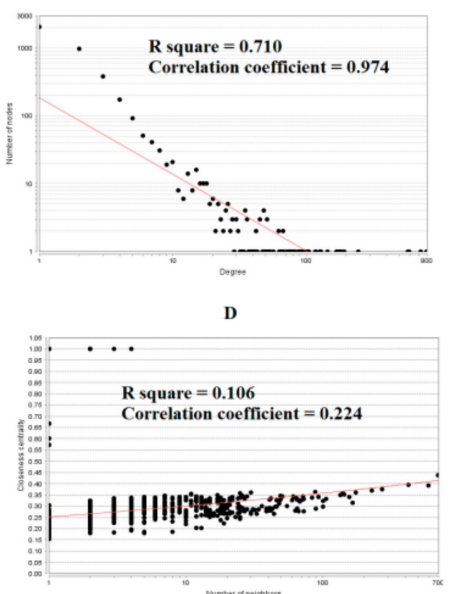

B

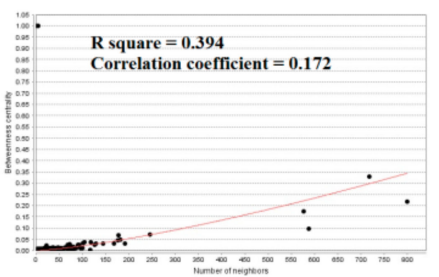

$\mathbf{E}$

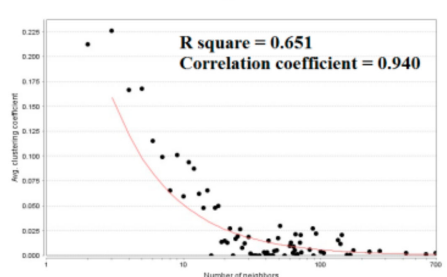

C

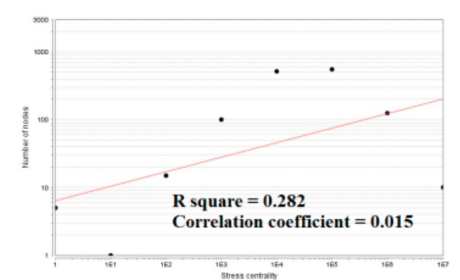

Figure 9. Regression diagrams for down regulated genes (A) Node degree; (B) Betweenness centrality; (C) Stress centrality; (D) Closeness centrality; (E) Clustering coefficient. 
After cluster analysis, according to the given parameters, four significant modules (module 4, module 5, module 12 and module 14) were obtained from PPI network for up regulated genes (Figure 10), while four significant modules (module 2, module 4, module 8 and module 13) were obtained from PPI network for down regulated genes (Figure 11). Pathway and GO enrichment analysis showed that up regulated genes in module 4, module 5, module 12 and module 14 were closely related to signaling pathways regulating pluripotency of stem cells, platinum drug resistance, negative regulation of immune system process and protein dimerization activity, while down regulated genes in module 2 , module 4, module 8 and module 13 were closely related to amb2 Integrin signaling, hypoxia-inducible factor in the cardiovascular system, platelet degranulation and response to inorganic substance.

Module 4

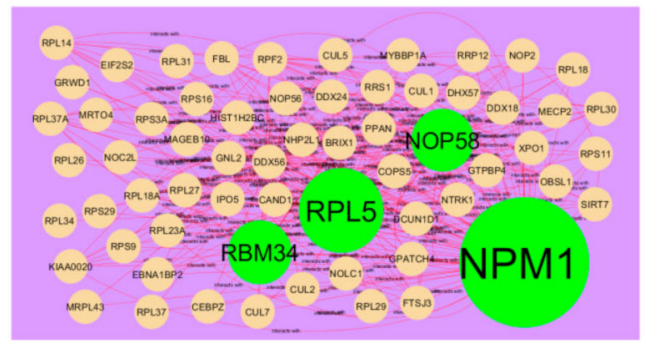

Module 12

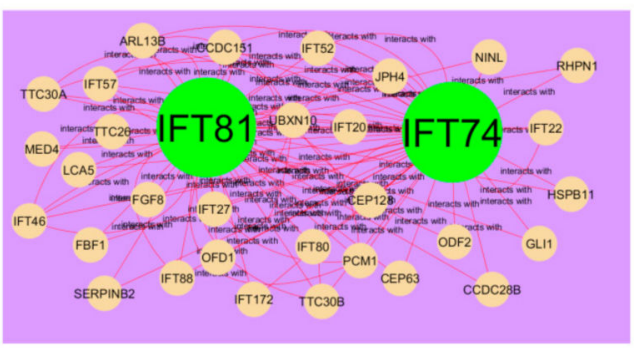

Module 5

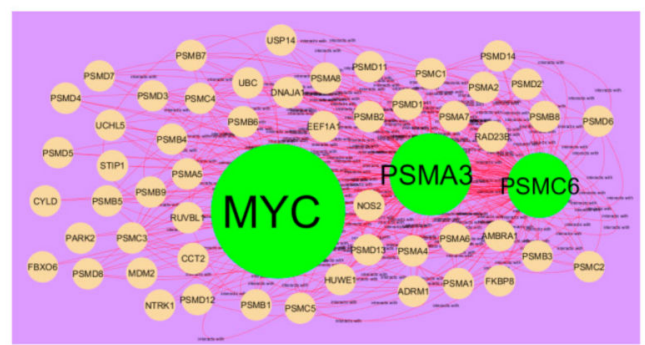

Module 14

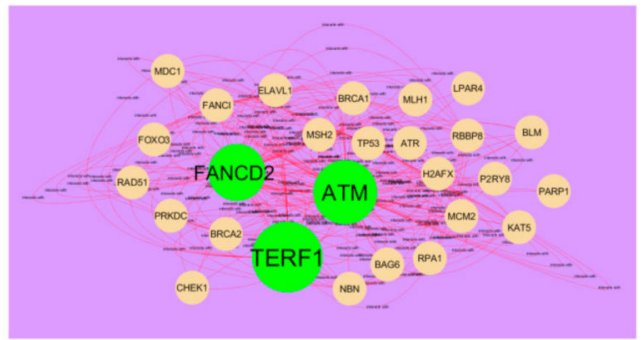

Figure 10. Modules in protein-protein interaction (PPI) network. The green nodes denote the up regulated genes.

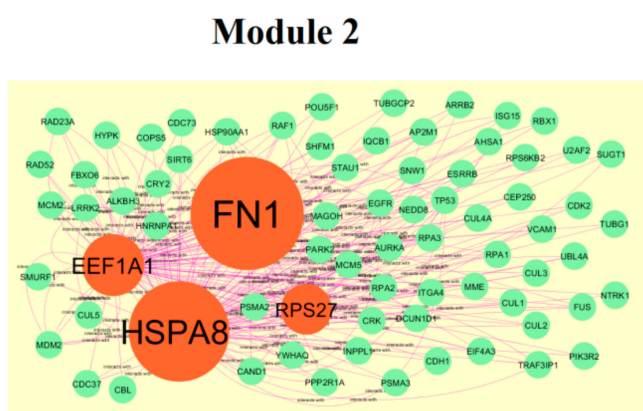

Module 8

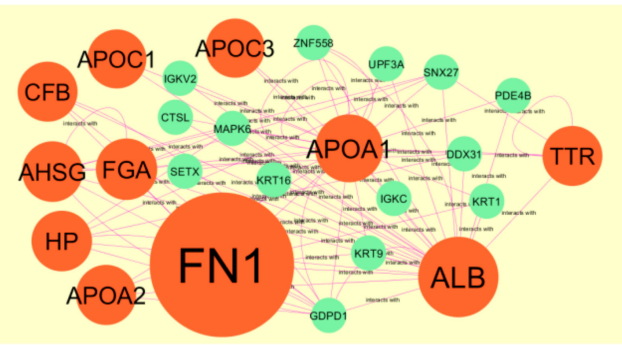

Module 4

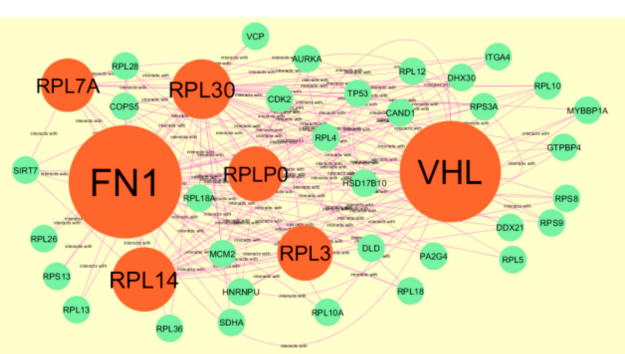

Module 13

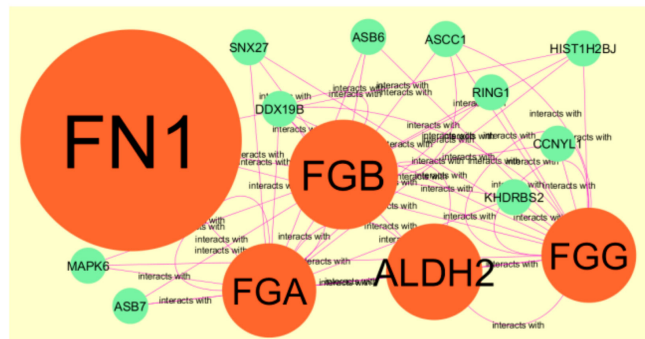

Figure 11. Modules in PPI network. The orange nodes denote the down regulated genes. 


\subsection{Construction of Target Genes-miRNA Regulatory Network}

MicroRNAs (miRNAs) expressions were responsible for progression of CAD [54]. The miRNAs that may control the up and down regulated target genes are shown in Figures 12 and 13 . Top five up regulated target genes such as TAOK1 interacts with 222 miRNAs (ex, hsa-mir-3941), HMGB1 interacts with 143 miRNAs (ex, hsa-mir-1183), ZNF708 interacts with 104 miRNAs (ex, hsa-mir-6832-5p), MYC interacts with 103 miRNAs (ex, hsa-mir-4662b) and ZNF101 interacts with 91 miRNAs (ex, hsa-mir-3187-3p) are listed in Table S7. Top five down regulated target genes such as KHSRP interacts with 178 miRNAs (ex, hsa-mir-548ac), TRIM72 interacts with 123 miRNAs (ex, hsa-mir-6890-3p), MLLT1 interacts with 95 miRNAs (ex, hsa-mir-5681a), C3 interacts with 93 miRNAs (ex, hsa-mir-3135b) and DDIT4 interacts with 82 miRNAs (ex, hsa-mir-3607-3p) are listed in Table S7.

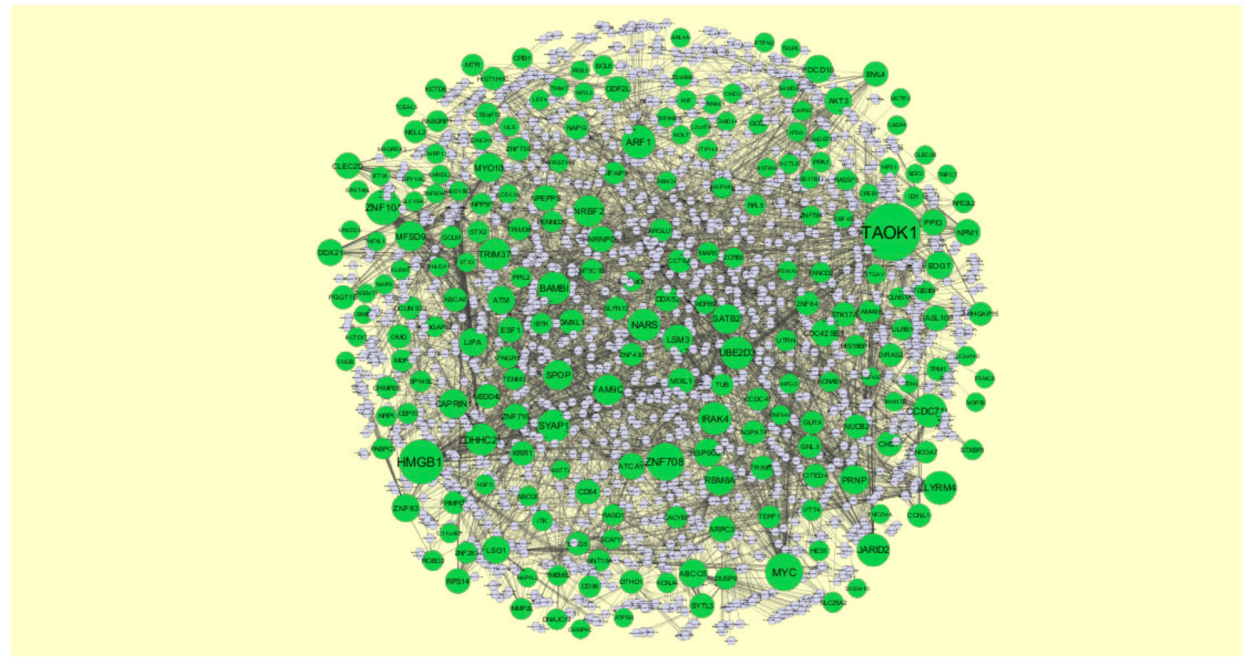

Figure 12. The network of up regulated genes and their related miRNAs. The green circles nodes are the up regulated genes, and white diamond nodes are the miRNAs.

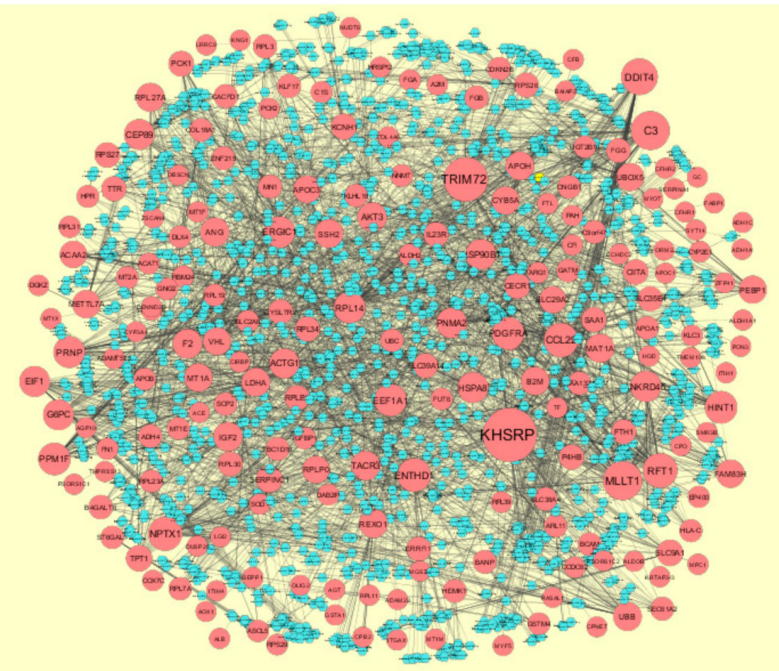

Figure 13. The network of down- regulated genes and their related miRNAs. The red circles nodes are the down regulated genes, and blue diamond nodes are the miRNAs.

\subsection{Construction of Target Genes-TF Regulatory Network}

Transcription factors (TFs) expressions were responsible for progression of CAD [55]. The TFs that may control the up and down regulated target genes are shown in Figures 14 and 15. Top five up regulated target genes such as HSD17B11 interacts with 166 TFs (ex, FOXC1), HEPACAM2 interacts 
with 128 TFs (ex, GATA2), CACYBP interacts with 88 TFs (ex, FOXL1), NAPG interacts with 76 TFs (ex, YY1) and PSMA3 interacts with 59 TFs (ex, USF2) are listed in Table S8. Top five down regulated target genes such as PAH interacts with 149 TFs (ex, FOXC1), CYP3A4 interacts with 118 TFs (ex, GATA2), CP interacts with 76 TFs (ex, YY1), COX7C interacts with 66 TFs (ex, SRF) and TTTY10 interacts with 59 TFs (ex, FOXL1) are listed in Table S8.

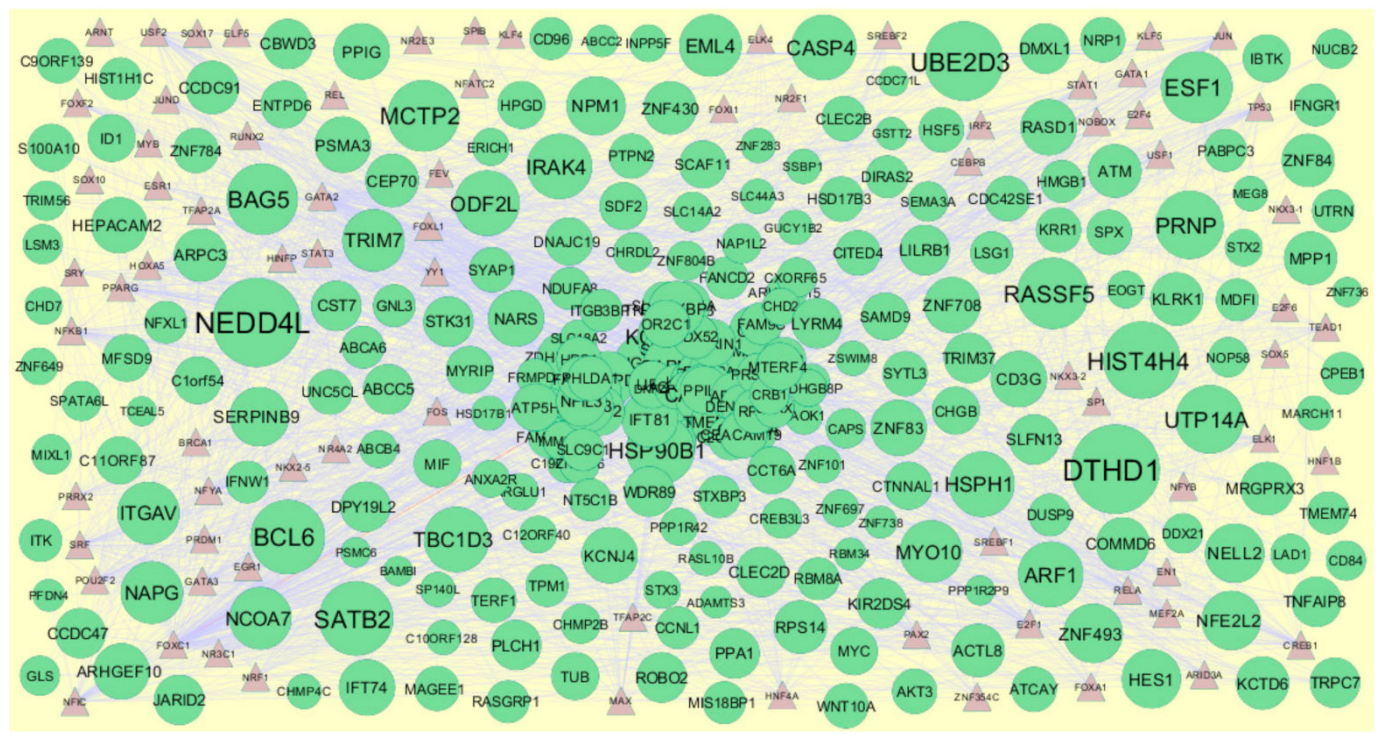

Figure 14. The network of up regulated genes and their related TFs. The green circles nodes are the up regulated genes, and brown triangle nodes are the TFs.

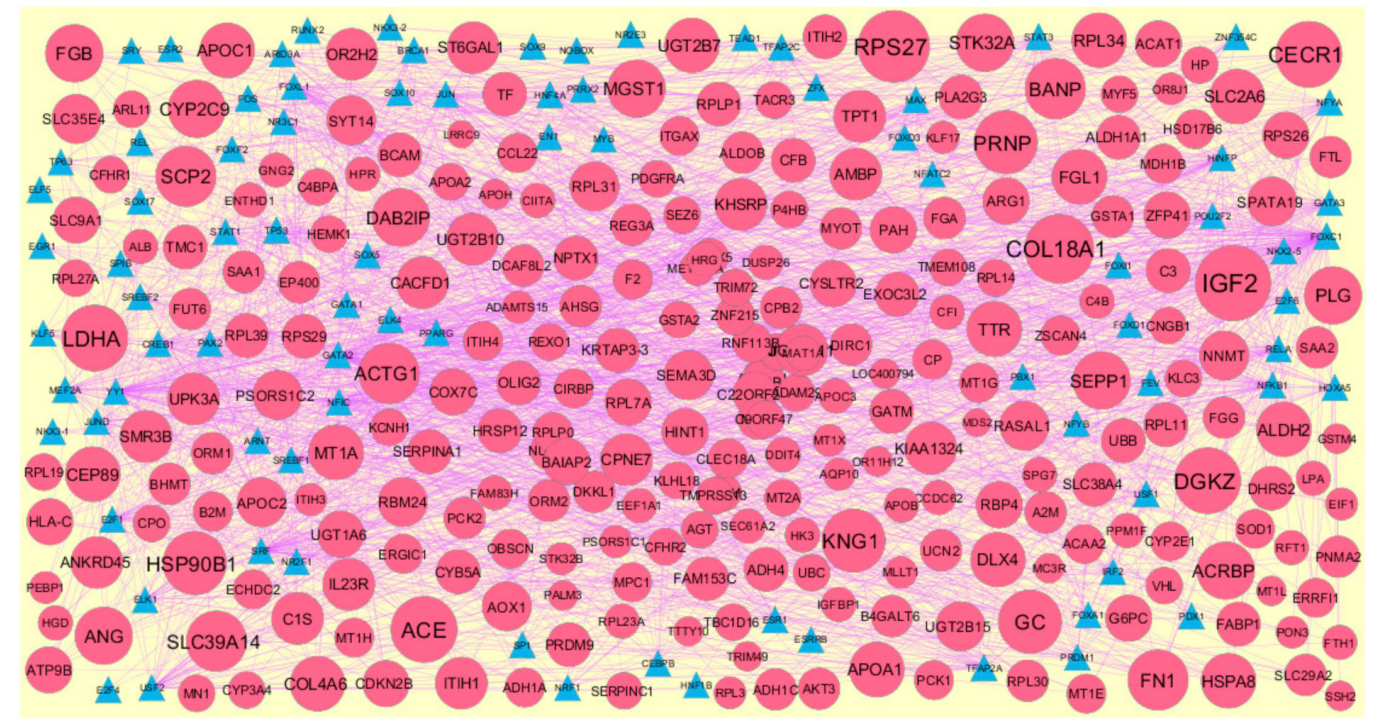

Figure 15. The network of down regulated genes and their related TFs. The green circles nodes are the down regulated genes, and blue triangle nodes are the TFs.

\subsection{Validation of Hub Genes by Immunohistochemistry from HPA Database and Receiver Operating Characteristic Curve analysis}

The analysis from The Human Protein Atlas indicated that the expression of hub genes (up regulated) such as NPM1, ATM, TRIP6, HSP90B1 and HIST1H1C are enhanced in CAD smooth muscle tissue (Figure 16), whereas, the expression of hub genes (down regulated) such as UBC, FN1, RPL14, UBB and EEF1A1 are reduced in CAD smooth muscle tissue (Figure 17). The results of ROC curve indicated that NPM1, TRIP6, HSP90B1, UBC, FN1, RPL14, UBB and EEF1A1 could distinguish 
male CAD samples from female CAD tissues best, among all the up and down regulated hub genes (NPM1: $\mathrm{AUC}=1$; $\mathrm{ATM}: \mathrm{AUC}=0.875$; TRIP6: $\mathrm{AUC}=1 ; \mathrm{HSP} 90 \mathrm{~B} 1: \mathrm{AUC}=1, \mathrm{HIST} 1 \mathrm{H} 1 \mathrm{C}: \mathrm{AUC}=0.938$; $\mathrm{UBC}: \mathrm{AUC}=1 ; \mathrm{FN1}: \mathrm{AUC}=1 ; \mathrm{RPL14}: \mathrm{AUC}=1 ; \mathrm{UBB}: \mathrm{AUC}=1 ; \mathrm{EEF1A1:} \mathrm{AUC}=1)($ Figure 18).
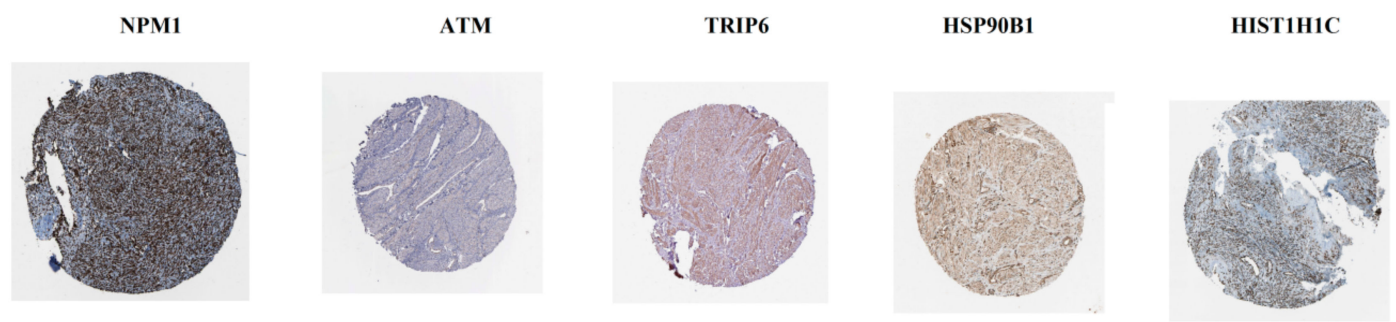

Figure 16. Validation of the hub genes (up regulated) with immunohistochemistry from HPA database. Hub genes NPM1, ATM, TRIP6, HSP90B1 and HIST1H1C were high expressed in CAD.
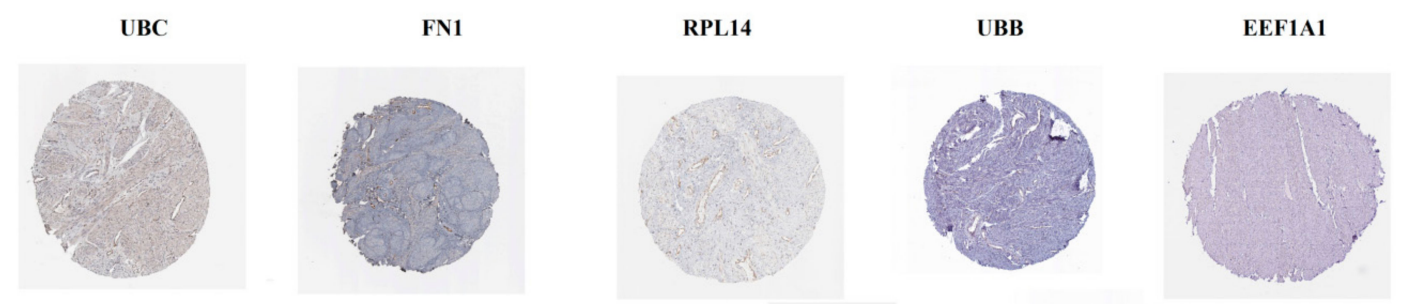

Figure 17. Validation of the hub genes (up regulated) with immunohistochemistry from HPA database. Hub genes UBC, FN1, RPL14, UBB and EEF1A1 were low expressed in CAD.
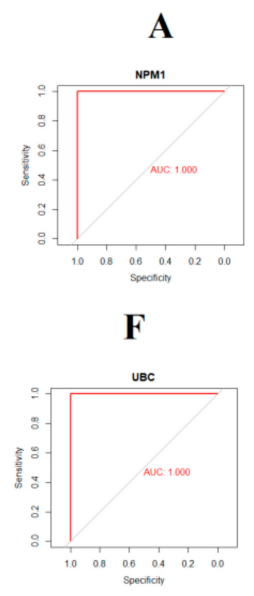

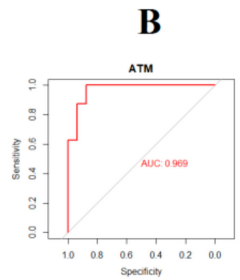

G

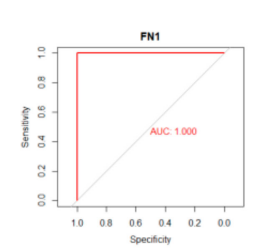

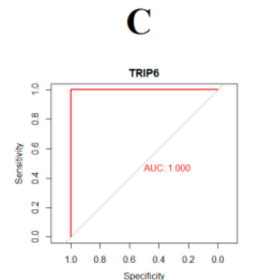

H

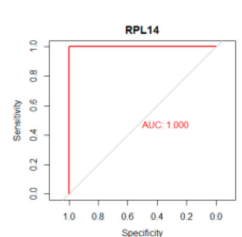

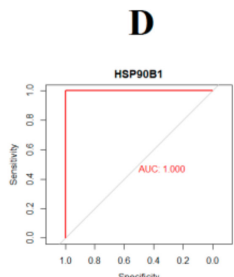
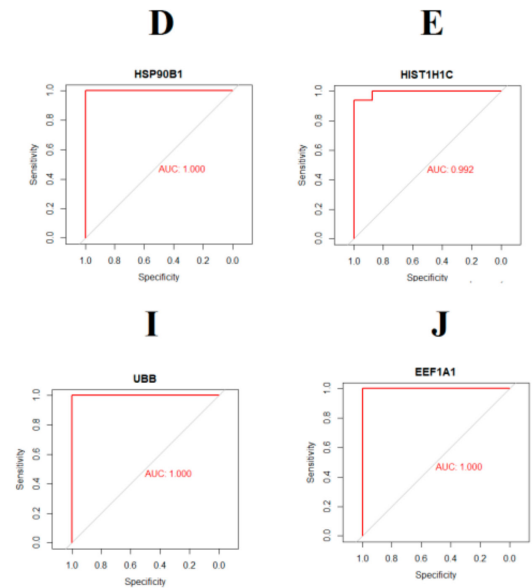

Figure 18. Receiver operating characteristic (ROC) curves and area under the curve (AUC) statistics to evaluate the diagnostic efficiency of the hub genes in GSE23766. (A) NPM1 (B) ATM (C) TRIP6 (D) HSP90B1 (E) HIST1H1C (F) UBC (G) FN1 (H) RPL14 (I) UBB (J) EEF1A1.

\section{Discussion}

The majority of patients with CAD are diagnosed at advanced stages and have poor overall survival [56]. However, the molecular mechanisms associated in the development of CAD remain unclear.

In the current study, the raw gene expression data of GSE23766 was obtained from the GEO and a total of 894 important DEGs were identified in male CAD samples compared with female CAD samples, including 456 up regulated genes and 438 down regulated genes. Low expression of LIN28 was associated with progression of cardiac ischaemia [57], but this gene may be linked with development of CAD. DUSP9 was involved in progression of cardiac hypertrophy [58], but this gene 
may be responsible for progression of CAD. Mutation in PSMC6 was important for progression of type 1 diabetes [59], but variation in this gene may be associated with the development of CAD. Decrease expression of ATP5H was liable for progression of mitochondrial dysfunction in cardiomyocytes [60], but low expression of this gene may be linked with the advancement of CAD. Genes such as IRAK4 [61], albumin (ALB) [62] and plasminogen (PLG) [63] were involved in progression of CAD. Alteration in SEPP1 was important for development of peripheral arterial disease [64], but modification in this gene may be liable for advancement of CAD. Polymorphism in ALDH2 was liable for development of CAD [65]. Modification in SERPINA1 was diagnosed with development of large artery stroke [66], but this altered gene may be liable for progression of CAD.

In pathway enrichment analysis, up regulated genes were enriched in various pathway databases such as superpathway of steroid hormone biosynthesis, ABC transporters, BARD1 signaling events, ABC-family proteins mediated transport, methionine metabolism, telomeres, telomerase, cellular aging, and immortality, androgen/estrogene/progesterone biosynthesis, multidrug resistance-associated protein mediated transport and lysosomal acid lipase deficiency (Wolman Disease). Mutation in HSD17B3 was linked with development of type 2 diabetes [67], but this variant gene may be responsible for progression of CAD. ABCG5 was linked with progression of CAD [68]. Mutation in ataxia telangiectasia mutated (ATM) was responsible for progression of CAD in male [69]. ABCC5 was expressed in heart disease [70], but this gene may be associated with advancement of CAD. Lysosomal acid, cholesterol esterase (LIPA) was important for development of CAD [71]. In these pathways genes such as HSD17B11, ABCB4, ABCC2, ABCA6, FANCD2, UBE2D3, NPM1, PSMA3, methionyl-tRNA synthetase (MARS), 5-methyltetrahydrofolate-homocysteine methyltransferase (MTR), v-myc myelocytomatosis viral oncogene homolog (avian) (MYC) and TERF1 were predicted as novel prognostic or diagnostic biomarkers and new therapeutic target in CAD. Up regulated genes such as ABCB4, ABCC2, ABCG5, ABCC5 and ABCA6 were involved in centralized pathway of $A B C$ transporters was associated with pathogenesis of CAD [72]. Down regulated genes were enriched in various pathway databases such as oxidative ethanol degradation III, complement and coagulation cascades, FOXA2 and FOXA3 transcription factor networks, metallothioneins bind metals, fatty acid metabolism, fibrinolysis pathway, plasminogen activating cascade, altered lipoprotein metabolic and enoxaparin pathway. Polymorphism in fibrinogen alpha chain (FGA) was liable for progression of myocardial infarction [73], but this polymorphic gene may be involved in pathogenesis of CAD. Fibrinogen gamma chain (FGG) was diagnosed with progression of ischemic stroke [74], but this gene may be identified with development of CAD. Increased expression of genes such as CPB2 was liable for advancement of myocardial infarction [75], but elevated expression of this gene may be associated with progression of CAD. Over expression of complement component 3 (C3) was responsible for advancement of CAD in female [76]. Low expression of C4B was culpable for pathogenesis of myocardial infarction [77], but decrease expression of this gene may be involved in progression of CAD. Genes such as APOA1 [78] IGFBP1 [79], ACAT1 [80], apolipoprotein B (APOB) [81] and APOC1 [82] were important for pathogenesis of CAD. Genes such as PCK1 [83] and ALDH1A1 [84] were associated with development of diabetes and obesity, but these genes may be linked with progression of CAD. Polymorphism in genes such as MT1A [85], MT2A [86], CYP2C9 [87], CYP3A4 [88], fibrinogen beta chain (FGB) [89], ADH1C [90], lipoprotein, Lp(a) (LPA) [91] and APOC3 [92] were liable for advancement of CAD. Alteration in APOC2 was involved in progression of hypertriglyceridaemia [93], but this gene may be responsible for the development of CAD. Down regulated genes such as ACAT1, ADH1A, ADH1C, ADH4, ACAA2, ALDH1A1, ALDH2, CYP2C9, CYP2E1, CYP3A4 were involved in centralized pathway of fatty acid metabolism was associated with pathogenesis of CAD [94]. In these pathways genes such as CYP2E1, A2M, coagulation factor II (thrombin) (F2), complement factor I (CFI), SERPINC1, integrin, alpha $X$ (complement component 3 receptor 4 subunit) (ITGAX), complement factor B (CFB), C1S, C4BPA, KNG1, transthyretin (prealbumin, amyloidosis type I) (TTR) aldolase B, fructose-bisphosphate (ALDOB), G6PC, MT1B, MT1E, MT1F, MT1G, MT1H, MT1M, MT1X, ADH1A, 
$\mathrm{ADH} 4$ and ACAA2 were predicted as novel prognostic or diagnostic biomarkers and new therapeutic targets in CAD.

In GO enrichment analysis, up regulated genes were enriched in all GO categories such as forebrain neuron differentiation, filopodium membrane and DNA binding, bending. SEMA3A was responsible for progression of myocardial infarction [95], but this gene may be associated with pathogenesis of CAD. Genes such as HES1 [96] and NRP1 [97] were important for progression of cardiac ischemia, but these genes may be linked with CAD. Loss of utrophin (UTRN) was involved in the advancement of cardiomyopathy [98], but this gene may be liable for progression of CAD. Increased expression of HMGB1 was answerable for progression of CAD [99]. In these GO categories, genes such as PHLDA1, SATB2, ROBO2, LEF1, MYO10 and integrin, alpha V (ITGAV) were predicted as novel prognostic or diagnostic biomarkers and new therapeutic target in CAD. Down regulated genes were enriched in all GO categories such as platelet degranulation, blood microparticle and peptidase regulator activity. Polymorphism in apolipoprotein $\mathrm{H}(\mathrm{APOH})$ was linked with progression of hypercholesterolemia [100], but this polymorphic gene may be liable for development of CAD. Genes such as IGF2 [101], ITIH4 [102], haptoglobin (HP) [103] and ceruloplasmin (ferroxidase) (CP) [104] were important for advancement of CAD. High expression of SOD1 was involved in the progression of CAD [105]. ITIH3 was answerable for advancement of myocardial infarction [106], but this gene may be associated with development of CAD. Transferrin (TF) was identified with progression of acute stroke [107], but this gene may be linked with development of CAD. Loss of CFHR1 was important for progression of hypertension [108], but loss this gene may be responsible for advancement of CAD. Polymorphism in genes such as angiotensinogen (AGT) [109] and HSPA8 [110] were important for theadvancement of CAD. In these GO categories genes such as alpha-2-HS-glycoprotein (AHSG), histidine-rich glycoprotein (HRG), FN1, ORM1, ORM2, TMPRSS13, ACTG1, haptoglobin-related protein (HPR), alpha-1-microglobulin/bikunin precursor (AMBP), APOA2, group-specific component (GC), ITIH1, ITIH2, acrosin binding protein (ACRBP) and PEBP1 were predicted as novel prognostic or diagnostic biomarkers and new therapeutic target in CAD.

In PPI network, up regulated genes such as MYC, NPM1, UBE2D3, TERF1, PSMA3, MDFI, CCT6A and RPS14 were identified as hub genes showing the highest node degree, betweenness, stress and closeness. Up regulated genes such as TRPC7, TNFRSF11B, ABCB4, DPY19L2 and ABCG5 were identified as hub genes showing the lowest clustering coefficient. TRPC7 was linked with development of CAD [111]. Polymorphism in TNFRSF11B was identified with development of ischemic stroke [112], but this gene may be important for progression of CAD. In this PPI network genes such as myoD family inhibitor (MDFI), CCT6A, RPS14 and DPY19L2 were predicted as novel prognostic or diagnostic biomarkers and new therapeutic target in CAD. Down regulated genes such as UBC, FN1, VHL, HSPA8 and SOD1 were identified as hub genes showing the highest node degree, betweenness, stress and closeness. Down regulated genes such as HEMK1, ADH1C, CYSLTR2, CYP2E1 and COX7C were identified as hub genes showing the lowest clustering coefficient. In this PPI network genes such as ubiquitin C (UBC), VHL (von Hippel-Lindau tumor suppressor), HEMK1, CYSLTR2 and COX7C were predicted as novel prognostic or diagnostic biomarkers and new therapeutic target in CAD.

In module analysis, up regulated genes such as NPM1, RPL5, NOP58, RBM34, MYC, PSMA3, PSMC6, IFT74 and IFT8 were identified as hub genes showing the highest node degree in all four significant modules. In these modules genes such as RPL5, NOP58, RBM34, IFT74 and IFT8 were predicted as novel prognostic or diagnostic biomarkers and new therapeutic target in CAD. Down regulated genes such as FN1, HSPA8, EEF1A1, RPS27, VHL, RPL7A, RPL30, RPLP0, RPL3, RPL14, ALB, TTR, APOA1, APOC3, APOC1, CFB, AHSG, FGA, HP, APOA2, FGB, FGG, ALDH2 and FGA were identified as hub genes showing the highest node degree in all four significant modules. In these modules genes such as EEF1A1, RPS27, RPL7A, RPL30, RPLP0, RPL3 and RPL14 were predicted as novel prognostic or diagnostic biomarkers and new therapeutic target in CAD.

In target gene-miRNA network, up regulated genes such as TAOK1, HMGB1, ZNF708, MYC and ZNF101 were identified as target genes showing the highest number of integration with miRNAs. 
In this network gene such as TAOK1, ZNF708 and ZNF101 along with miRNA such as hsa-mir-3941, hsa-mir-1183, hsa-mir-6832-5p, hsa-mir-4662b and hsa-mir-3187-3p were predicted as novel prognostic or diagnostic biomarkers and new therapeutic target in CAD. Whereas, down regulated genes such as KHSRP, TRIM72, MLLT1, C3 and DDIT4 were identified as target genes showing the highest number of integration with miRNAs. Low expression of TRIM72 was responsible for development of cardiovascular diseases [113], but loss of this gene may be linked with progression of CAD. In this network down regulated genes such as KH-type splicing regulatory protein (FUSE binding protein 2) (KHSRP), MLLT1 and DDIT4 along with miRNA such as hsa-mir-548ac, hsa-mir-6890-3p, hsa-mir-5681a, hsa-mir-3135b and hsa-mir-3607-3p were predicted as novel prognostic or diagnostic biomarkers and new therapeutic target in CAD.

In the target gene-TF network, up regulated genes such as HSD17B11, HEPACAM2, CACYBP, NAPG and PSMA3 were identified as target genes showing the highest number of integration with TFs. In this network genes such as HEPACAM2, calcyclin binding protein (CACYBP) and N-ethylmaleimide-sensitive factor attachment protein, gamma (NAPG) along TFs such as FOXC1, FOXL1, YY1 and USF2 were predicted as novel prognostic or diagnostic biomarkers and new therapeutic target in CAD. Transcription factor GATA2 was linked with pathogens of CAD [114]. Down regulated genes such as PAH, CYP3A4, CP, COX7C and TTTY10 were identified as target genes showing the highest number of integration with TFs. Phenylalanine hydroxylase (PAH) was associated with development of cardiovascular diseases [115], but this gene may be identified with advancement of CAD. In this network down regulated gene TTTY10 along transcription factor SRF (serum response factor) were predicted as novel prognostic or diagnostic biomarkers and new therapeutic target in CAD.

In conclusion, the present study identified 13 hub genes (up regulated) and 10 hub genes (down regulated) that may be associated in the progression of CAD. Among them, 12 hub genes (up regulated) and 7 hub genes (down regulated) are closely related to the prognosis of CAD. Also identified 10 miRNA and 10 TFs may be associated in the progression of CAD. These hub genes may be regarded as diagnostic and prognostic biomarkers, and could become potential therapeutic target for future $\mathrm{CAD}$ therapeutic strategies. However, bioinformatics only plays a predictive role; the function of these hub genes in CAD needs further study to elucidate the biological characteristics.

Supplementary Materials: The following are available online at http://www.mdpi.com/2218-273X/10/1/35/s1.

Author Contributions: M.V.B. was associated with project administration and acquisition of resources. T.B.S. was associated with methodology and formal analysis. S.N. was associated with review and editing, and visualization. B.V. was participated in writing original draft and investigation, C.V. was performed software, supervision, formal analysis and validation. All authors have read and agreed to the published version of the manuscript.

Funding: This research received no external funding.

Acknowledgments: I thank David J. Waxman, Boston University, Department of Biology and Bioinformatics Program, 5 Cummington Mall, Boston, MA, USA, very much, the author who deposited their microarray dataset, GSE23766, into the public GEO database.

Conflicts of Interest: The authors declare no conflict of interest.

Ethical Approval: This article does not contain any studies with human participants or animals performed by any of the authors.

Informed Consent: No informed consent because this study does not contain human or animals participants.

Availability of Data and Materials: The datasets supporting the conclusions of this article are available in the GEO (Gene Expression Omnibus) (https://www.ncbi.nlm.nih.gov/geo/) repository. [(GSE23766) (https: //www.ncbi.nlm.nih.gov/geo/query/acc.cgi?acc=GSE23766)].

Consent for Publication: Not applicable.

\section{References}

1. Diamond, G.A.; Forrester, J.S. Analysis of probability as an aid in the clinical diagnosis of coronary-artery disease. N. Engl. J. Med. 1979, 300, 1350-1358. [CrossRef] [PubMed] 
2. Ghassibe-Sabbagh, M.; Platt, D.E.; Youhanna, S.; Abchee, A.B.; Stewart, K.; Badro, D.A.; Haber, M.; Salloum, A.K.; Douaihy, B.; el Bayeh, H. Genetic and environmental influences on total plasma homocysteine and its role in coronary artery disease risk. Atherosclerosis 2012, 222, 180-186. [CrossRef] [PubMed]

3. Howson, J.M.; Zhao, W.; Barnes, D.R.; Ho, W.K.; Young, R.; Paul, D.S.; Waite, L.L.; Freitag, D.F.; Fauman, E.B.; Salfati, E.L.; et al. Fifteen new risk loci for coronary artery disease highlight arterial-wall-specific mechanisms. Nat. Genet. 2017, 49, 1113-1119. [CrossRef] [PubMed]

4. Aceña, Á.; Pello, A.M.; Carda, R.; Lorenzo, Ó.; Gonzalez-Casaus, M.L.; Blanco-Colio, L.M.; Martín-Ventura, J.L.; Palfy, J.; Orejas, M.; Rábago, R.; et al. Parathormone Levels Are Independently Associated with the Presence of Left Ventricular Hypertrophy in Patients with Coronary Artery Disease. J. Nutr. Health Aging 2016, 20, 659-664. [CrossRef] [PubMed]

5. Samani, N.J.; Erdmann, J.; Hall, A.S.; Hengstenberg, C.; Mangino, M.; Maye, R.B.; Dixon, R.J.; Meitinger, T.; Braund, P.; Wichmann, H.E.; et al. Genomewide association analysis of coronary artery disease. N. Engl. J. Med. 2007, 357, 443-453. [CrossRef] [PubMed]

6. Clee, S.M.; Zwinderman, A.H.; Engert, J.C.; Zwarts, K.Y.; Molhuizen, H.O.; Roomp, K.; Jukema, J.W.; van Wijland, M.; van Dam, M.; Hudson, T.J.; et al. Common genetic variation in ABCA1 is associated with altered lipoprotein levels and a modified risk for coronary artery disease. Circulation 2001, 103, 1198-1205. [CrossRef]

7. Serrato, M.; Marian, A.J. A variant of human paraoxonase/arylesterase (HUMPONA) gene is a risk factor for coronary artery disease. J. Clin. Investig. 1995, 96, 3005-3008. [CrossRef]

8. Behague, I.; Poirier, O.; Nicaud, V.; Evans, A.; Arveiler, D.; Luc, G.; Cambou, J.P.; Scarabin, P.Y.; Bara, L.; Green, F.; et al. Beta fibrinogen gene polymorphisms are associated with plasma fibrinogen and coronary artery disease in patients with myocardial infarction. The ECTIM Study. Etude Cas-Temoins sur l'Infarctus du Myocarde. Circulation 1996, 93, 440-449. [CrossRef]

9. Ordovas, J.M.; Schaefer, E.J.; Salem, D.; Ward, R.H.; Glueck, C.J.; Vergani, C.; Wilson, P.W.; Karathanasis, S.K. Apolipoprotein A-I gene polymorphism associated with premature coronary artery disease and familial hypoalphalipoproteinemia. N. Engl. J. Med. 1986, 314, 671-677. [CrossRef]

10. Kaneda, H.; Ohno, M.; Taguchi, J.; Togo, M.; Hashimoto, H.; Ogasawara, K.; Aizawa, T.; Ishizaka, N.; Nagai, R. Heme oxygenase-1 gene promoter polymorphism is associated with coronary artery disease in Japanese patients with coronary risk factors. Arterioscler. Thromb. Vasc. Biol. 2002, 22, 1680-1685. [CrossRef]

11. Sanghera, D.K.; Aston, C.E.; Saha, N.; Kamboh, M.I. DNA polymorphisms in two paraoxonase genes (PON1 and PON2) are associated with the risk of coronary heart disease. Am. J. Hum. Genet. 1998, 62, 36-44. [CrossRef] [PubMed]

12. Margaglione, M.; Cappucci, G.; Colaizzo, D.; Giuliani, N.; Vecchione, G.; Grandone, E.; Pennelli, O.; Di Minno, G. The PAI-1 gene locus $4 \mathrm{G} / 5 \mathrm{G}$ polymorphism is associated with a family history of coronary artery disease. Arterioscler. Thromb. Vasc. Biol. 1998, 18, 152-156. [CrossRef] [PubMed]

13. Lamblin, N.; Bauters, C.; Hermant, X.; Lablanche, J.M.; Helbecque, N.; Amouyel, P. Polymorphisms in the promoter regions of MMP-2, MMP-3, MMP-9 and MMP-12 genes as determinants of aneurysmal coronary artery disease. J. Am. Coll. Cardiol. 2002, 40, 43-48. [CrossRef]

14. Inoue, N.; Kawashima, S.; Kanazawa, K.; Yamada, S.; Akita, H.; Yokoyama, M. Polymorphism of the NADH/NADPH oxidase p22 phox gene in patients with coronary artery disease. Circulation 1998, 97, 135-137. [CrossRef] [PubMed]

15. Amant, C.; Hamon, M.; Bauters, C.; Richard, F.; Helbecque, N.; McFadden, E.P.; Escudero, X.; Lablanche, J.M.; Amouyel, P.; Bertrand, M.E. The angiotensin II type 1 receptor gene polymorphism is associated with coronary artery vasoconstriction. J. Am. Coll. Cardiol. 1997, 29, 486-490. [CrossRef]

16. Ma, J.; Liew, C.C. Gene profiling identifies secreted protein transcripts from peripheral blood cells in coronary artery disease. J. Mol. Cell. Cardiol. 2003, 35, 993-998. [CrossRef]

17. Archacki, S.R.; Angheloiu, G.; Tian, X.L.; Tan, F.L.; DiPaola, N.; Shen, G.Q.; Moravec, C.; Ellis, S.; Topol, E.J.; Wang, Q. Identification of new genes differentially expressed in coronary artery disease by expression profiling. Physiol. Genom. 2003, 15, 65-74. [CrossRef]

18. Carvalho, B.S.; Irizarry, R.A. A framework for oligonucleotide microarray preprocessing. Bioinformatics 2010, 6, 2363-2367. [CrossRef]

19. Ritchie, M.E.; Phipson, B.; Wu, D.; Hu, Y.; Law, C.W.; Shi, W.; Smyth, G.K. limma powers differential expression analyses for RNA-sequencing and microarray studies. Nucleic Acids Res. 2015, 43, e47. [CrossRef] 
20. Chen, J.; Bardes, E.E.; Aronow, B.J.; Jegga, A.G. ToppGene Suite for gene list enrichment analysis and candidate gene prioritization. Nucleic Acids Res. 2009, 37, W305-W311. [CrossRef]

21. Aoki-Kinoshita, K.F.; Kanehisa, M. Gene annotation and pathway mapping in KEGG. Methods. Mol. Biol. 2007, 396, 71-91. [CrossRef] [PubMed]

22. Schaefer, C.F.; Anthony, K.; Krupa, S.; Buchoff, J.; Day, M.; Hannay, T.; Buetow, K.H. PID: The Pathway Interaction Database. Nucleic Acids Res. 2009, 37, D674-D679. [CrossRef] [PubMed]

23. Croft, D.; O’Kelly, G.; Wu, G.; Haw, R.; Gillespie, M.; Matthews, L.; Caudy, M.; Garapati, P.; Gopinath, G.; Jassal, B.; et al. Reactome: A database of reactions, pathways and biological processes. Nucleic Acids Res. 2011, 39, D691-D697. [CrossRef] [PubMed]

24. Liberzon, A.; Subramanian, A.; Pinchback, R.; Thorvaldsdóttir, H.; Tamayo, P.; Mesirov, J.P. Molecular signatures database (MSigDB) 3.0. Bioinformatics 2011, 27, 1739-1740. [CrossRef]

25. Dahlquist, K.D.; Salomonis, N.; Vranizan, K.; Lawlor, S.C.; Conklin, B.R. GenMAPP, a new tool for viewing and analyzing microarray data on biological pathways. Nat. Genet. 2002, 31, 19-20. [CrossRef]

26. Petri, V.; Jayaraman, P.; Tutaj, M.; Hayman, G.T.; Smith, J.R.; De Pons, J.; Laulederkind, S.J.; Lowry, T.F.; Nigam, R.; Wang, S.J.; et al. The pathway ontology-updates and applications. J. Biomed. Semant. 2014, 5, 7. [CrossRef]

27. Mi, H.; Muruganujan, A.; Thomas, P.D. PANTHER in 2013: Modeling the evolution of gene function, and other gene attributes, in the context of phylogenetic trees. Nucleic Acids Res. 2013, 41, D377-D386. [CrossRef]

28. Harris, M.A.; Clark, J.; Ireland, A.; Lomax, J.; Ashburner, M.; Foulger, R.; Eilbeck, K.; Lewis, S.; Marshall, B.; Mungall, C.; et al. The Gene Ontology (GO) database and informatics. Nucleic Acids Res. 2004, 32, D258-D261. [CrossRef]

29. Oughtred, R.; Stark, C.; Breitkreutz, B.J.; Rust, J.; Boucher, L.; Chang, C.; Kolas, N.; O’Donnell, L.; Leung, G.; McAdam, R.; et al. The BioGRID interaction database: 2019 update. Nucleic Acids Res. 2019, 47, D529-D541. [CrossRef]

30. Licata, L.; Briganti, L.; Peluso, D.; Perfetto, L.; Iannuccelli, M.; Galeota, E.; Sacco, F.; Palma, A.; Nardozza, A.P.; Santonico, E.; et al. MINT, the molecular interaction database: 2012 update. Nucleic Acids Res. 2012, 40, D857-D861. [CrossRef]

31. Orchard, S.; Kerrien, S.; Abbani, S.; Aranda, B.; Bhate, J.; Bidwell, S.; Bridge, A.; Briganti, L.; Brinkman, F.S.; Chatr-Aryamontri, A.; et al. Protein interaction data curation: The International Molecular Exchange (IMEx) consortium. Nat. Methods 2012, 9, 345-350. [CrossRef] [PubMed]

32. Salwinski, L.; Miller, C.S.; Smith, A.J.; Pettit, F.K.; Bowie, J.U.; Eisenberg, D. The Database of Interacting Proteins: 2004 update. Nucleic Acids Res. 2004, 32, D449-D451. [CrossRef] [PubMed]

33. Cerami, E.G.; Gross, B.E.; Demir, E.; Rodchenkov, I.; Babur, O.; Anwar, N.; Schultz, N.; Bader, G.D.; Sander, C. Pathway Commons, a web resource for biological pathway data. Nucleic Acids Res. 2011, 39, D685-D690. [CrossRef] [PubMed]

34. Razick, S.; Magklaras, G.; Donaldson, I.M. iRefIndex: A consolidated protein interaction database with provenance. BMC Bioinform. 2008, 9, 405. [CrossRef] [PubMed]

35. Szklarczyk, D.; Gable, A.L.; Lyon, D.; Junge, A.; Wyder, S.; Huerta-Cepas, J.; Simonovic, M.; Doncheva, N.T.; Morris, J.H.; Bork, P.; et al. STRING v11: Protein-protein association networks with increased coverage, supporting functional discovery in genome-wide experimental datasets. Nucleic Acids Res. 2019, 47, D607-D613. [CrossRef]

36. Clerc, O.; Deniaud, M.; Vallet, S.D.; Naba, A.; Rivet, A.; Perez, S.; Thierry-Mieg, N.; Ricard-Blum, S. MatrixDB: Integration of new data with a focus on glycosaminoglycan interactions. Nucleic Acids Res. 2019, 47, D376-D381. [CrossRef]

37. Goll, J.; Rajagopala, S.V.; Shiau, S.C.; Wu, H.; Lamb, B.T.; Uetz, P. MPIDB: The microbial protein interaction database. Bioinformatics 2008, 24, 1743-1744. [CrossRef]

38. Breuer, K.; Foroushani, A.K.; Laird, M.R.; Chen, C.; Sribnaia, A.; Lo, R.; Winsor, G.L.; Hancock, R.E.; Brinkman, F.S.; Lynn, D.J. InnateDB: Systems biology of innate immunity and beyond-recent updates and continuing curation. Nucleic Acids Res. 2013, 41, D1228-D1233. [CrossRef]

39. Turner, B.; Razick, S.; Turinsky, A.L.; Vlasblom, J.; Crowdy, E.K.; Cho, E.; Morrison, K.; Donaldson, I.M.; Wodak, S.J. iRefWeb: Interactive analysis of consolidated protein interaction data and their supporting evidence. Database 2010, 2010, baq023. [CrossRef] 
40. Kotlyar, M.; Pastrello, C.; Sheahan, N.; Jurisica, I. Integrated interactions database: Tissue-specific view of the human and model organism interactomes. Nucleic Acids Res. 2016, 44, D536-D541. [CrossRef]

41. Shannon, P.; Markiel, A.; Ozier, O.; Baliga, N.S.; Wang, J.T.; Ramage, D.; Amin, N.; Schwikowski, B.; Ideker, T. Cytoscape: A software environment for integrated models of biomolecular interaction networks. Genome Res. 2003, 3, 2498-2504. [CrossRef] [PubMed]

42. Przulj, N. Biological network comparison using graphlet degree distribution. Bioinformatics 2007, 23, e177-e183. [CrossRef] [PubMed]

43. Yang, Q.; Lonardi, S. A parallel edge-betweenness clustering tool for Protein-Protein Interaction networks. Int. J. Data Min. Bioinform. 2007, 1, 241-247. [CrossRef] [PubMed]

44. Bi, D.; Ning, H.; Liu, S.; Que, X.; Ding, K. Gene expression patterns combined with network analysis identify hub genes associated with bladder cancer. Comput. Biol. Chem. 2015, 56, 71-83. [CrossRef] [PubMed]

45. Xiao, Q.; Wang, J.; Peng, X.; Wu, F.X.; Pan, Y. Identifying essential proteins from active PPI networks constructed with dynamic gene expression. BMC Genom. 2015, 16. [CrossRef] [PubMed]

46. Asur, S.; Ucar, D.; Parthasarathy, S. An ensemble framework for clustering protein-protein interaction networks. Bioinformatics 2007, 23, i29-i40. [CrossRef]

47. Zaki, N.; Efimov, D.; Berengueres, J. Protein complex detection using interaction reliability assessment and weighted clustering coefficient. BMC Bioinform. 2013, 14, 163. [CrossRef]

48. Vlachos, I.S.; Paraskevopoulou, M.D.; Karagkouni, D.; Georgakilas, G.; Vergoulis, T.; Kanellos, I.; Anastasopoulos, I.L.; Maniou, S.; Karathanou, K.; Kalfakakou, D.; et al. DIANA-TarBase v7.0: Indexing more than half a million experimentally supported miRNA:mRNA interactions. Nucleic Acids Res. 2015, 43, D153-D159. [CrossRef]

49. Chou, C.H.; Shrestha, S.; Yang, C.D.; Chang, N.W.; Lin, Y.L.; Liao, K.W.; Huang, W.C.; Sun, T.H.; Tu, S.J.; Lee, W.H.; et al. miRTarBase update 2018: A resource for experimentally validated microRNA-target interactions. Nucleic Acids Res. 2018, 46, D296-D302. [CrossRef]

50. Zhou, G.; Soufan, O.; Ewald, J.; Hancock, R.E.W.; Basu, N.; Xia, J. NetworkAnalyst 3.0: A visual analytics platform for comprehensive gene expression profiling and meta-analysis. Nucleic Acids Res. 2019. [CrossRef]

51. Khan, A.; Fornes, O.; Stigliani, A.; Gheorghe, M.; Castro-Mondragon, J.A.; van der Lee, R.; Bessy, A.; Chèneby, J.; Kulkarni, S.R.; Tan, G.; et al. JASPAR 2018: Update of the open-access database of transcription factor binding profiles and its web framework. Nucleic Acids Res. 2018, 46, D260-D266. [CrossRef] [PubMed]

52. Uhlen, M.; Oksvold, P.; Fagerberg, L.; Lundberg, E.; Jonasson, K.; Forsberg, M.; Zwahlen, M.; Kampf, C.; Wester, K.; Hober, S.; et al. Towards a knowledge-based Human Protein Atlas. Nat. Biotechnol. 2010, 28, 1248-1250. [CrossRef]

53. Robin, X.; Turck, N.; Hainard, A.; Tiberti, N.; Lisacek, F.; Sanchez, J.C.; Müller, M. pROC: An open-source package for R and $\mathrm{S}+$ to analyze and compare ROC curves. BMC Bioinform. 2011, 12, 77. [CrossRef] [PubMed]

54. Zhong, Z.; Hou, J.; Zhang, Q.; Zhong, W.; Li, B.; Li, C.; Liu, Z.; Yang, M.; Zhao, P. Circulating microRNA expression profiling and bioinformatics analysis of dysregulated microRNAs of patients with coronary artery disease. Medicine 2018, 97, e11428. [CrossRef] [PubMed]

55. Bhagavatula, M.R.; Fan, C.; Shen, G.Q.; Cassano, J.; Plow, E.F.; Topol, E.J.; Wang, Q. Transcription factor MEF2A mutations in patients with coronary artery disease. Hum. Mol. Genet. 2004, 13, 3181-3188. [CrossRef]

56. Detrano, R.; Janosi, A.; Steinbrunn, W.; Pfisterer, M.; Schmid, J.J.; Sandhu, S.; Guppy, K.H.; Lee, S.; Froelicher, V. International application of a new probability algorithm for the diagnosis of coronary artery disease. Am. J. Cardiol. 1989, 64, 304-310. [CrossRef]

57. Joshi, S.; Wei, J.; Bishopric, N.H. A cardiac myocyte-restricted Lin28/let-7 regulatory axis promotes hypoxia-mediated apoptosis by inducing the AKT signaling suppressor PIK3IP1. Biochim. Biophys. Acta 2016, 1862, 240-251. [CrossRef]

58. Singh, G.B.; Raut, S.K.; Khanna, S.; Kumar, A.; Sharma, S.; Prasad, R.; Khullar, M. MicroRNA-200c modulates DUSP-1 expression in diabetes-induced cardiac hypertrophy. Mol. Cell. Biochem. 2017, 424, 1-11. [CrossRef]

59. Sjakste, T.; Paramonova, N.; Osina, K.; Dokane, K.; Sokolovska, J.; Sjakste, N. Genetic variations in the PSMA3, PSMA6 and PSMC6 genes are associated with type 1 diabetes in Latvians and with expression level of number of UPS-related and T1DM-susceptible genes in HapMap individuals. Mol. Genet. Genom. 2016, 291, 891-903. [CrossRef] 
60. Wang, H.W.; Zhao, W.P.; Liu, J.; Tan, P.P.; Tian, W.S.; Zhou, B.H. ATP5J and ATP5H Proactive Expression Correlates with Cardiomyocyte Mitochondrial Dysfunction Induced by Fluoride. Biol. Trace Elem. Res. 2017, 180, 63-69. [CrossRef]

61. Rekhter, M.; Staschke, K.; Estridge, T.; Rutherford, P.; Jackson, N.; Gifford-Moore, D.; Foxworthy, P.; Reidy, C.; Huang, X.D.; Kalbfleisch, M.; et al. Genetic ablation of IRAK4 kinase activity inhibits vascular lesion formation. Biochem. Biophys. Res. Commun. 2008, 367, 642-648. [CrossRef] [PubMed]

62. Gorinstein, S.; Caspi, A.; Libman, I.; Katrich, E.; Lerner, H.T.; Trakhtenberg, S. Fresh israeli jaffa sweetie juice consumption improves lipid metabolism and increases antioxidant capacity in hypercholesterolemic patients suffering from coronary artery disease: Studies in vitro and in humans and positive changes in albumin and fibrinogen fractions. J. Agric. Food. Chem. 2004, 52, 5215-5222. [CrossRef] [PubMed]

63. Schaefer, A.S.; Bochenek, G.; Jochens, A.; Ellinghaus, D.; Dommisch, H.; Güzeldemir-Akçakanat, E.; Graetz, C.; Harks, I.; Jockel-Schneider, Y.; Weinspach, K.; et al. Genetic evidence for PLASMINOGEN as a shared genetic risk factor of coronary artery disease and periodontitis. Circ. Cardiovasc. Genet. 2015, 8, 159-167. [CrossRef] [PubMed]

64. Strauss, E.; Oszkinis, G.; Staniszewski, R. SEPP1 gene variants and abdominal aortic aneurysm: Gene association in relation to metabolic risk factors and peripheral arterial disease coexistence. Sci. Rep. 2014, 4, 7061. [CrossRef] [PubMed]

65. Guo, Y.J.; Chen, L.; Bai, Y.P.; Li, L.; Sun, J.; Zhang, G.G.; Yang, T.L.; Xia, J.; Li, Y.J.; Chen, X.P. The ALDH2 Glu504Lys polymorphism is associated with coronary artery disease in Han Chinese: Relation with endothelial ADMA levels. Atherosclerosis 2010, 211, 545-550. [CrossRef] [PubMed]

66. Malik, R.; Dau, T.; Gonik, M.; Sivakumar, A.; Deredge, D.J.; Edeleva, E.V.; Götzfried, J.; van der Laan, S.W.; Pasterkamp, G.; Beaufort, N.; et al. Common coding variant in SERPINA1 increases the risk for large artery stroke. Proc. Natl. Acad. Sci. USA 2017, 114, 3613-3618. [CrossRef]

67. Rotroff, D.M.; Pijut, S.S.; Marvel, S.W.; Jack, J.R.; Havener, T.M.; Pujol, A.; Schluter, A.; Graf, G.A.; Ginsberg, H.N.; Shah, H.S.; et al. Genetic Variants in HSD17B3, SMAD3, and IPO11 Impact Circulating Lipids in Response to Fenofibrate in Individuals with Type 2 Diabetes. Clin. Pharmacol. 2018, 103, 712-721. [CrossRef]

68. Yu, X.H.; Qian, K.; Jiang, N.; Zheng, X.L.; Cayabyab, F.S.; Tang, C.K. ABCG5/ABCG8 in cholesterol excretion and atherosclerosis. Clin. Chim. Acta 2014, 428, 82-88. [CrossRef]

69. Schiekofer, S.; Bobak, I.; Kleber, M.E.; Maerz, W.; Rudofsky, G.; Dugi, K.A.; Schneider, J.G. Association between a gene variant near ataxia telangiectasia mutated and coronary artery disease in men. Diabetes Vasc. Dis. Res. 2014, 11, 60-63. [CrossRef]

70. Dazert, P.; Meissner, K.; Vogelgesang, S.; Heydrich, B.; Eckel, L.; Böhm, M.; Warzok, R.; Kerb, R.; Brinkmann, U.; Schaeffeler, E.; et al. Expression and localization of the multidrug resistance protein 5 (MRP5/ABCC5), a cellular export pump for cyclic nucleotides, in human heart. Am. J. Pathol. 2003, 163, 1567-1577. [CrossRef]

71. Wild, P.S.; Zeller, T.; Schillert, A.; Szymczak, S.; Sinning, C.R.; Deiseroth, A.; Schnabel, R.B.; Lubos, E.; Keller, T.; Eleftheriadis, M.S.; et al. A genome-wide association study identifies LIPA as a susceptibility gene for coronary artery disease. Circ. Cardiovasc. Genet. 2011, 4, 403-412. [CrossRef] [PubMed]

72. Westerterp, M.; Bochem, A.E.; Yvan-Charvet, L.; Murphy, A.J.; Wang, N.; Tall, A.R. ATP-binding cassette transporters, atherosclerosis, and inflammation. Circ. Res. 2014, 114, 157-170. [CrossRef] [PubMed]

73. Jacquemin, B.; Antoniades, C.; Nyberg, F.; Plana, E.; Müller, M.; Greven, S.; Salomaa, V.; Sunyer, J.; Bellander, T.; Chalamandaris, A.G.; et al. Common genetic polymorphisms and haplotypes of fibrinogen alpha, beta, and gamma chains affect fibrinogen levels and the response to proinflammatory stimulation in myocardial infarction survivors: The AIRGENE study. J. Am. Coll. Cardiol. 2008, 52, 941-952. [CrossRef] [PubMed]

74. Cheung, E.Y.; Uitte de Willige, S.; Vos, H.L.; Leebeek, F.W.; Dippel, D.W.; Bertina, R.M.; de Maat, M.P. Fibrinogen gamma' in ischemic stroke: A case-control study. Stroke 2008, 39, 1033-1035. [CrossRef]

75. Leenaerts, D.; Bosmans, J.M.; van der Veken, P.; Sim, Y.; Lambeir, A.M.; Hendriks, D. Plasma levels of carboxypeptidase $\mathrm{U}$ (CPU, CPB2 or TAFIa) are elevated in patients with acute myocardial infarction. J. Thromb. Haemost 2015, 13, 2227-2232. [CrossRef]

76. Széplaki, G.; Prohászka, Z.; Duba, J.; Rugonfalvi-Kiss, S.; Karádi, I.; Kókai, M.; Kramer, J.; Füst, G.; Kleiber, M.; Romics, L.; et al. Association of high serum concentration of the third component of complement (C3) with pre-existing severe coronary artery disease and new vascular events in women. Atherosclerosis 2004, 177, 383-389. [CrossRef] 
77. Blaskó, B.; Kolka, R.; Thorbjornsdottir, P.; Sigurdarson, S.T.; Sigurdsson, G.; Rónai, Z.; Sasvári-Székely, M.; Bödvarsson, S.; Thorgeirsson, G.; Prohászka, Z.; et al. Low complement C4B gene copy number predicts short-term mortality after acute myocardial infarction. Int. Immunol. 2008, 20, 31-37. [CrossRef]

78. Shanker, J.; Perumal, G.; Rao, V.S.; Khadrinarasimhiah, N.B.; John, S.; Hebbagodi, S.; Mukherjee, M.; Kakkar, V.V. Genetic studies on the APOA1-C3-A5 gene cluster in Asian Indians with premature coronary artery disease. Lipids Health Dis. 2008, 7, 33. [CrossRef]

79. Heald, A.H.; Cruickshank, J.K.; Riste, L.K.; Cade, J.E.; Anderson, S.; Greenhalgh, A.; Sampayo, J.; Taylor, W.; Fraser, W.; White, A.; et al. Close relation of fasting insulin-like growth factor binding protein-1 (IGFBP-1) with glucose tolerance and cardiovascular risk in two populations. Diabetologia 2001, 44, 333-339. [CrossRef]

80. Miyazaki, A.; Sakashita, N.; Lee, O.; Takahashi, K.; Horiuchi, S.; Hakamata, H.; Morganelli, P.M.; Chang, C.C.; Chang, T.Y. Expression of ACAT-1 protein in human atherosclerotic lesions and cultured human monocytes-macrophages. Arterioscler. Thromb. Vasc. Biol. 1998, 18, 1568-1574. [CrossRef]

81. Thompson, A.; Danesh, J. Associations between apolipoprotein B, apolipoprotein AI, the apolipoprotein B/AI ratio and coronary heart disease: A literature-based meta-analysis of prospective studies. J. Intern. Med. 2006, 259, 481-492. [CrossRef] [PubMed]

82. Chang, C.T.; Liao, H.Y.; Chang, C.M.; Chen, C.Y.; Chen, C.H.; Yang, C.Y.; Tsai, F.J.; Chen, C.J. Oxidized ApoC1 on MALDI-TOF and glycated-ApoA1 band on gradient gel as potential diagnostic tools for atherosclerotic vascular disease. Clin. Chim. Acta 2013, 420, 69-75. [CrossRef] [PubMed]

83. Beale, E.G.; Harvey, B.J.; Forest, C. PCK1 and PCK2 as candidate diabetes and obesity genes. Cell Biochem. Biophys. 2007, 48, 89-95. [CrossRef] [PubMed]

84. Landrier, J.F.; Kasiri, E.; Karkeni, E.; Mihály, J.; Béke, G.; Weiss, K.; Lucas, R.; Aydemir, G.; Salles, J.; Walrand, S.; et al. Reduced adiponectin expression after high-fat diet is associated with selective up-regulation of ALDH1A1 and further retinoic acid receptor signaling in adipose tissue. FASEB J. 2017, 31, $203-211$. [CrossRef] [PubMed]

85. Giacconi, R.; Bonfigli, A.R.; Testa, R.; Sirolla, C.; Cipriano, C.; Marra, M.; Muti, E.; Malavolta, M.; Costarelli, L.; Piacenza, F.; et al. +647 A/C and +1245 MT1A polymorphisms in the susceptibility of diabetes mellitus and cardiovascular complications. Mol. Genet. Metab. 2008, 94, 98-104. [CrossRef]

86. Yang, X.Y.; Sun, J.H.; Ke, H.Y.; Chen, Y.J.; Xu, M.; Luo, G.H. Metallothionein 2A genetic polymorphism and its correlation to coronary heart disease. Eur. Rev. Med. Pharmacol. Sci. 2014, 18, 3747-3753.

87. Ercan, B.; Ayaz, L.; Ciçek, D.; Tamer, L. Role of CYP2C9 and CYP2C19 polymorphisms in patients with atherosclerosis. Cell. Biochem. Funct. 2008, 26, 309-313. [CrossRef]

88. He, B.X.; Shi, L.; Qiu, J.; Tao, L.; Li, R.; Yang, L.; Zhao, S.J. A functional polymorphism in the CYP3A4 gene is associated with increased risk of coronary heart disease in the Chinese Han population. Basic. Clin. Pharmacol. Toxicol. 2011, 108, 208-213. [CrossRef]

89. Li, Y.Y.; Wu, X.Y.; Xu, J.; Qian, Y.; Zhou, C.W.; Wang, B. Apo A5 -1131T/C, FgB -455G/A, -148C/T, and CETP TaqIB gene polymorphisms and coronary artery disease in the Chinese population: A meta-analysis of 15,055 subjects. Mol. Biol. Rep. 2013, 40, 1997-2014. [CrossRef]

90. Ebrahim, S.; Lawlor, D.A.; Shlomo, Y.B.; Timpson, N.; Harbord, R.; Christensen, M.; Baban, J.; Kiessling, M.; Day, I.; Gaunt, T.; et al. Alcohol dehydrogenase type 1C (ADH1C) variants, alcohol consumption traits, HDL-cholesterol and risk of coronary heart disease in women and men: British Women's Heart and Health Study and Caerphilly cohorts. Atherosclerosis 2008, 196, 871-878. [CrossRef]

91. Clarke, R.; Peden, J.F.; Hopewell, J.C.; Kyriakou, T.; Goel, A.; Heath, S.C.; Parish, S.; Barlera, S.; Franzosi, M.G.; Rust, S.; et al. Genetic variants associated with Lp(a) lipoprotein level and coronary disease. N. Engl. J. Med. 2009, 361, 2518-2528. [CrossRef]

92. Russo, G.T.; Meigs, J.B.; Cupples, L.A.; Demissie, S.; Otvos, J.D.; Wilson, P.W.; Lahoz, C.; Cucinotta, D.; Couture, P.; Mallory, T.; et al. Association of the Sst-I polymorphism at the APOC3 gene locus with variations in lipid levels, lipoprotein subclass profiles and coronary heart disease risk: The Framingham offspring study. Atherosclerosis 2001, 158, 173-181. [CrossRef]

93. Siguel, E.N.; Lerman, R.H. Altered fatty acid metabolism in patients with angiographically documented coronary artery disease. Metabolism 1994, 43, 982-993. [CrossRef]

94. Surendran, R.P.; Visser, M.E.; Heemelaar, S.; Wang, J.; Peter, J.; Defesche, J.C.; Kuivenhoven, J.A.; Hosseini, M.; Péterfy, M.; Kastelein, J.J.; et al. Mutations in LPL, APOC2, APOA5, GPIHBP1 and LMF1 in patients with severe hypertriglyceridaemia. J. Intern. Med. 2012, 272, 185-196. [CrossRef] [PubMed] 
95. Rienks, M.; Carai, P.; Bitsch, N.; Schellings, M.; Vanhaverbeke, M.; Verjans, J.; Cuijpers, I.; Heymans, S.; Papageorgiou, A. Sema3A promotes the resolution of cardiac inflammation after myocardial infarction. Basic Res. Cardiol. 2017, 112, 42. [CrossRef]

96. Yu, L.; Li, Z.; Dong, X.; Xue, X.; Liu, Y.; Xu, S.; Zhang, J.; Han, J.; Yang, Y.; Wang, H. Polydatin Protects Diabetic Heart against Ischemia-Reperfusion Injury via Notch1/Hes1-Mediated Activation of Pten/Akt Signaling. Oxid. Med. Cell. Longev. 2018, 2018, 2750695. [CrossRef]

97. Wang, Y.; Cao, Y.; Yamada, S.; Thirunavukkarasu, M.; Nin, V.; Joshi, M.; Rishi, M.T.; Bhattacharya, S.; Camacho-Pereira, J.; Sharma, A.K.; et al. Cardiomyopathy and Worsened Ischemic Heart Failure in SM22- $\alpha$ Cre-Mediated Neuropilin-1 Null Mice: Dysregulation of PGC1 $\alpha$ and Mitochondrial Homeostasis. Arterioscler. Thromb. Vasc. Biol. 2015, 35, 1401-1412. [CrossRef]

98. Chun, J.L.; O'Brien, R.; Berry, S.E. Cardiac dysfunction and pathology in the dystrophin and utrophin-deficient mouse during development of dilated cardiomyopathy. Neuromuscul. Disord. 2012, 22, 368-379. [CrossRef]

99. Yan, X.X.; Lu, L.; Peng, W.H.; Wang, L.J.; Zhang, Q.; Zhang, R.Y.; Chen, Q.J.; Shen, W.F. Increased serum HMGB1 level is associated with coronary artery disease in nondiabetic and type 2 diabetic patients. Atherosclerosis 2009, 205, 544-548. [CrossRef]

100. Takada, D.; Ezura, Y.; Ono, S.; Iino, Y.; Katayama, Y.; Xin, Y.; Wu, L.L.; Larringa-Shum, S.; Stephenson, S.H.; Hunt, S.C.; et al. Apolipoprotein $\mathrm{H}$ variant modifies plasma triglyceride phenotype in familial hypercholesterolemia: A molecular study in an eight-generation hyperlipidemic family. J. Atheroscler. Thromb. 2003, 10, 79-84. [CrossRef]

101. Rodríguez, S.; Gaunt, T.R.; O’Dell, S.D.; Chen, X.H.; Gu, D.; Hawe, E.; Miller, G.J.; Humphries, S.E.; Day, I.N. Haplotypic analyses of the IGF2-INS-TH gene cluster in relation to cardiovascular risk traits. Hum. Mol. Genet. 2004, 13, 715-725. [CrossRef] [PubMed]

102. Xu, H.; Shang, Q.; Chen, H.; Du, J.; Wen, J.; Li, G.; Shi, D.; Chen, K. ITIH4: A New Potential Biomarker of "Toxin Syndrome" in Coronary Heart Disease Patient Identified with Proteomic Method. Evid. Based. Complement. Alternat. Med. 2013, 2013, 360149. [CrossRef] [PubMed]

103. Cahill, L.E.; Levy, A.P.; Chiuve, S.E.; Jensen, M.K.; Wang, H.; Shara, N.M.; Blum, S.; Howard, B.V.; Pai, J.K.; Mukamal, K.J.; et al. Haptoglobin genotype is a consistent marker of coronary heart disease risk among individuals with elevated glycosylated hemoglobin. J. Am. Coll. Cardiol. 2013, 61, 728-737. [CrossRef] [PubMed]

104. Hammadah, M.; Fan, Y.; Wu, Y.; Hazen, S.L.; Tang, W.H. Prognostic value of elevated serum ceruloplasmin levels in patients with heart failure. J. Card. Fail. 2014, 20, 946-952. [CrossRef] [PubMed]

105. Tanaka, M.; Mokhtari, G.K.; Terry, R.D.; Balsam, L.B.; Lee, K.H.; Kofidis, T.; Tsao, P.S.; Robbins, R.C. Overexpression of human copper/zinc superoxide dismutase (SOD1) suppresses ischemia-reperfusion injury and subsequent development of graft coronary artery disease in murine cardiac grafts. Circulation 2004, 110, II200-II206. [CrossRef] [PubMed]

106. Ebana, Y.; Ozaki, K.; Inoue, K.; Sato, H.; Iida, A.; Lwin, H.; Saito, S.; Mizuno, H.; Takahashi, A.; Nakamura, T.; et al. A functional SNP in ITIH3 is associated with susceptibility to myocardial infarction. J. Hum. Genet. 2007, 52, 220-229. [CrossRef]

107. Altamura, C.; Squitti, R.; Pasqualetti, P.; Gaudino, C.; Palazzo, P.; Tibuzzi, F.; Lupoi, D.; Cortesi, M.; Rossini, P.M.; Vernieri, F. Ceruloplasmin/Transferrin system is related to clinical status in acute stroke. Stroke 2009, 40, 1282-1288. [CrossRef]

108. Gan, W.; Wu, J.; Lu, L.; Xiao, X.; Huang, H.; Wang, F.; Zhu, J.; Sun, L.; Liu, G.; Pan, Y.; et al. Associations of CFH polymorphisms and CFHR1-CFHR3 deletion with blood pressure and hypertension in Chinese population. PLoS ONE 2012, 7, e42010. [CrossRef]

109. Renner, W.; Nauck, M.; Winkelmann, B.R.; Hoffmann, M.M.; Scharnagl, H.; Mayer, V.; Boehm, B.O.; März, W. Association of angiotensinogen haplotypes with angiotensinogen levels but not with blood pressure or coronary artery disease: The Ludwigshafen Risk and Cardiovascular Health Study. J. Mol. Med. 2005, 83, 235-239. [CrossRef]

110. He, M.; Guo, H.; Yang, X.; Zhou, L.; Zhang, X.; Cheng, L.; Zeng, H.; Hu, F.B.; Tanguay, R.M.; Wu, T. Genetic variations in HSPA8 gene associated with coronary heart disease risk in a Chinese population. PLoS ONE 2010, 5, e9684. [CrossRef] 
111. Peppiatt-Wildman, C.M.; Albert, A.P.; Saleh, S.N.; Large, W.A. Endothelin-1 activates a Ca ${ }^{2+}$-permeable cation channel with TRPC3 and TRPC7 properties in rabbit coronary artery myocytes. J. Physiol. 2007, 580, 755-764. [CrossRef] [PubMed]

112. Biscetti, F.; Straface, G.; Giovannini, S.; Santoliquido, A.; Angelini, F.; Santoro, L.; Porreca, C.F.; Pecorini, G.; Ghirlanda, G.; Flex, A. Association between TNFRSF11B gene polymorphisms and history of ischemic stroke in Italian diabetic patients. Hum. Genet. 2013, 132, 49-55. [CrossRef] [PubMed]

113. Zhao, J.; Lei, H. Tripartite Motif Protein 72 Regulates the Proliferation and Migration of Rat Cardiac Fibroblasts via the Transforming Growth Factor- $\beta$ Signaling Pathway. Cardiology 2016, 134, 340-346. [CrossRef] [PubMed]

114. Muiya, N.P.; Wakil, S.; Al-Najai, M.; Tahir, A.I.; Baz, B.; Andres, E.; Al-Boudari, O.; Al-Tassan, N.; Al-Shahid, M.; Meyer, B.F.; et al. A study of the role of GATA2 gene polymorphism in coronary artery disease risk traits. Gene 2014, 544, 152-158. [CrossRef] [PubMed]

115. Murr, C.; Grammer, T.B.; Meinitzer, A.; Kleber, M.E.; März, W.; Fuchs, D. Immune activation and inflammation in patients with cardiovascular disease are associated with higher phenylalanine to tyrosine ratios: The ludwigshafen risk and cardiovascular health study. J. Amino Acids 2014, 2014, 783730. [CrossRef]

(C) 2019 by the authors. Licensee MDPI, Basel, Switzerland. This article is an open access article distributed under the terms and conditions of the Creative Commons Attribution (CC BY) license (http://creativecommons.org/licenses/by/4.0/). 